\section{RESEARCH ARTICLE 10.1029/2019JC015546 \\ New Insight Into the Formation and Evolution of the East Reykjanes Ridge Current and Irminger Current}

Key Points:

- Flows from the Iceland Basin and across the Reykjanes Ridge drive along-stream evolution of the East Reykjanes Ridge Current

- The Irminger Current is shaped not only by the westward cross-ridge flow but by inflow from the western subpolar gyre south of about $59.5^{\circ} \mathrm{N}$

- North of $59^{\circ} \mathrm{N}$, the Irminger Current branches tilt northwestward and are joined by two additional branches from the cross-ridge flow

Supporting Information:

- Supporting Information S1

- Figure S1

- Figure S2

Correspondence to:

T. Petit,

tillys.petit@gmail.com

Citation:

Petit, T., Mercier, H., \& Thierry, V. (2019). New Insight Into the Formation and Evolution of the East Reykjanes Ridge Current and Irminger Current. Journal of Geophysical Research: Oceans, 124, 9171-9189. https:// doi.org/10.1029/2019JC015546

Received 5 AUG 2019 Accepted 6 NOV 2019

Accepted article online 11 NOV 2019 Published online 17 DEC 2019

\author{
T. Petit ${ }^{1}$ iD, H. Mercier ${ }^{2}$ iD, and V. Thierry ${ }^{1}$ (D) \\ ${ }^{1}$ IFREMER, Univ-Brest, CNRS, IRD, Laboratoire d'Océanographie Physique et Spatiale (LOPS), IUEM, F-29280, \\ Plouzané, France, ${ }^{2}$ Univ-Brest, CNRS, IFREMER, IRD, Laboratoire d'Océanographie Physique et Spatiale (LOPS), IUEM, \\ F-29280, Plouzané, France
}

\begin{abstract}
The Reykjanes Ridge strongly influences the circulation of the North Atlantic Subpolar Gyre as it flows to the Irminger Sea from the Iceland Basin. The circulation is composed of two main along-ridge currents: the southwestward East Reykjanes Ridge Current (ERRC) in the Iceland Basin and the northeastward Irminger Current (IC) in the Irminger Sea. To study their interconnection through the ridge, as well as their connections with the interior of each basin, velocity and hydrological measurements were carried out along and perpendicular to the crest of the Reykjanes Ridge in June-July 2015 as part of the Reykjanes Ridge Experiment project. This new data set changes our view of the ERRC and IC as it reveals undocumented along-stream evolutions of their hydrological properties, structures, and transports. These evolutions are due to flows connecting the ERRC and IC branches at specific locations set by the bathymetry of the ridge and to significant connections with the interiors of the basins. Overall, the ERRC transport increases by $3.2 \mathrm{~Sv}$ between $63^{\circ} \mathrm{N}$ and $59.5^{\circ} \mathrm{N}$ and remains almost constantly southward. In the Irminger Sea, the increase in IC transport of $13.7 \mathrm{~Sv}$ between $56^{\circ} \mathrm{N}$ and $59.5^{\circ} \mathrm{N}$, and the evolution of its properties are explained by both cross-ridge flows and inflows from the Irminger Sea. Further north, bathymetry steers the IC northwestward into the Irminger Sea. At $63^{\circ} \mathrm{N}$, the IC water masses are mostly issued from the crossridge flow.
\end{abstract}

Plain Language Summary Along pathways in the North Atlantic Subpolar Gyre, the warm and salty water of the North Atlantic Current is densified by intense winter air-sea buoyancy loss. This transformation preconditions this water mass for convection in the Irminger and Labrador Seas. Good knowledge of circulation in the Iceland Basin and Irminger Sea, strongly influenced by the Reykjanes Ridge, is needed to understand the along-stream evolution of its properties. Two main conduits flow anticyclonically around the Reykjanes Ridge: the East Reykjanes Ridge Current (ERRC) in the Iceland Basin and the Irminger Current in the Irminger Sea. From in-situ measurements carried out in the vicinity of the Reykjanes Ridge, we first investigated the along-stream evolution of the ERRC and IC properties and structures and show their interconnections through the complex bathymetry of the Reykjanes Ridge as well as their connections with the interiors of the basins. Contrary to what has been generally thought, we found that the ERRC and IC do not flow continuously into one top-to-bottom current along the ridge but are composed of complex inflows and outflows that locally modify the strength and properties of the ERRC and IC.

\section{Introduction}

The topography of the northern North Atlantic Ocean is composed of a succession of basins and ridges that constrain the horizontal circulation of the subpolar gyre. Among these, the Reykjanes Ridge, which is located between the Iceland Basin and the Irminger Sea, composes the northern part of the Mid-Atlantic Ridge. This major topographic feature extends southwest of Iceland and terminates at the Charlie Gibbs Fracture Zone (CGFZ) at $35^{\circ} \mathrm{W} / 52.5^{\circ} \mathrm{N}$ (Figure 1).

The circulation scheme in Figure 1 is an overall view of the mean circulation in the northern North Atlantic Ocean adapted from Daniault et al. (2016). The northeastward North Atlantic Current (NAC) is an extension of the Gulf Stream and bounds the cyclonic circulation of the subpolar gyre to the south. Divided into three main branches, the NAC is dynamically constrained to cross the Mid-Atlantic Ridge eastward above deep fracture zones (Bower \& Furey, 2017; Bower \& von Appen, 2008; Roessler et al., 2015; Schott et al., 1999). Some of these branches flow cyclonically in the Iceland Basin and reach the eastern flank of the
(C)2019. American Geophysical Union. All Rights Reserved. 


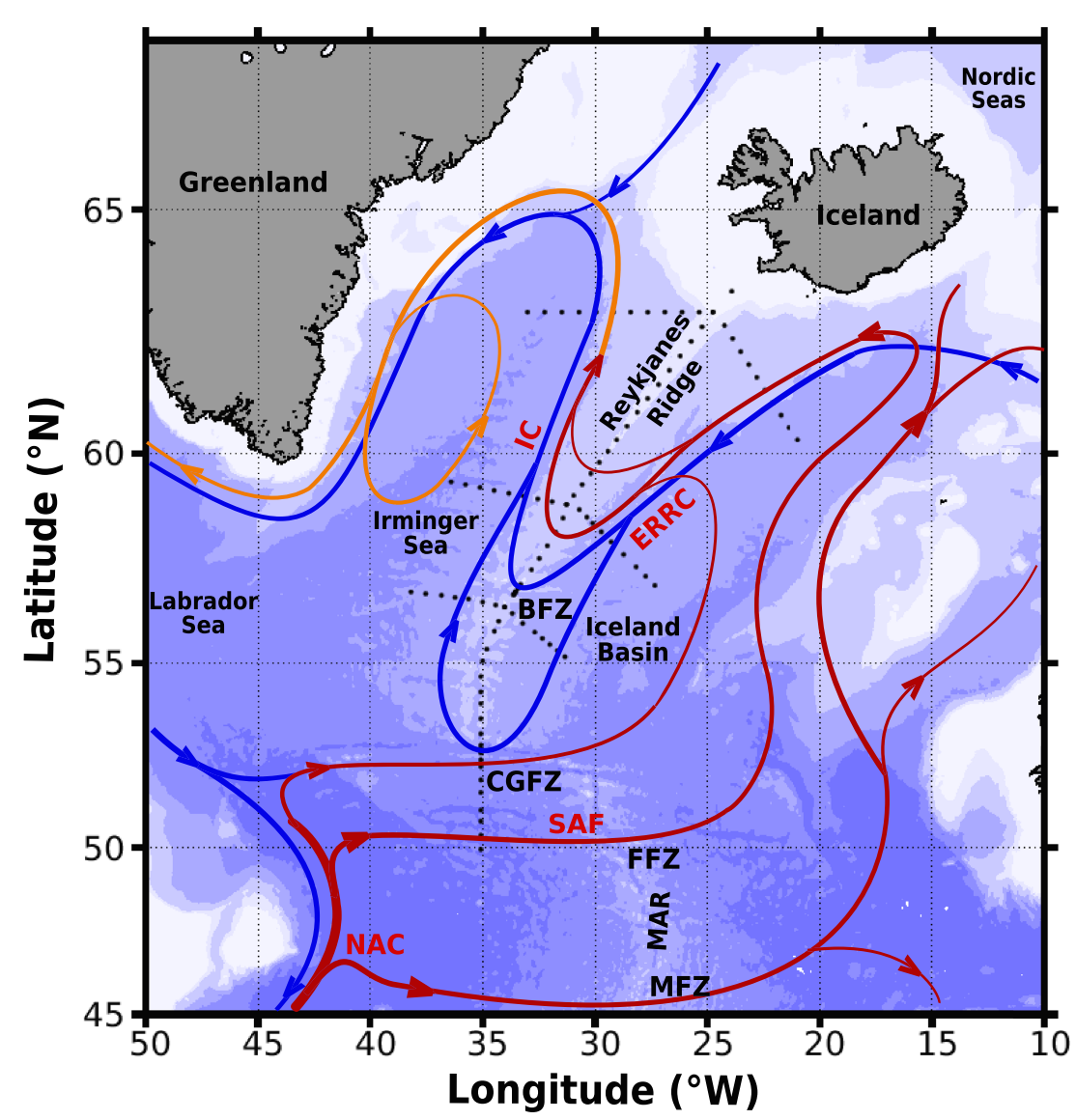

Figure 1. Schematic of large-scale circulation in the northern North Atlantic adapted from Daniault et al. (2016). Red, orange, and blue arrows depict surface, intermediate, and deep flows, respectively. Locations of the hydrographic stations where measurements were carried out along four sections during the RREX2015 cruise are overlaid (black dots). Bathymetry is plotted in color with color changes at 500,1,000, and every 1,000 m below 1,000 m. Topographical features of the North Atlantic are labeled: Bight Fracture Zone (BFZ), Charlie-Gibbs Fracture Zone (CGFZ), Faraday Fracture Zone (FFZ), Maxwell Fracture Zone (MFZ), Mid-Atlantic Ridge (MAR). The main associated currents are indicated: North Atlantic Currents (NAC), subarctic front (SAF), East Reykjanes Ridge Current (ERRC) and Irminger Current (IC).

Reykjanes Ridge. There the top-to-bottom current is constrained by the bathymetry of the Reykjanes Ridge to flow anticyclonically around and across the ridge. Based on the data from the Reykjanes Ridge Experiment (RREX), Petit, Mercier, et al. (2018) provided the first direct estimates of cross-ridge exchanges in terms of volume and properties between the Iceland Basin and Irminger Sea. They showed that the westward flows preferentially cross the ridge at $59-62^{\circ} \mathrm{N}$ and near $57^{\circ} \mathrm{N}$. These flows are associated with a sharp deepening of the crest of the Reykjanes Ridge south of $62^{\circ} \mathrm{N}$ and with the Bight Fracture Zone (BFZ) near $57^{\circ}$ N. Overall, $21.9 \pm 2.5 \mathrm{~Sv}$ crossed the Reykjanes Ridge toward the Irminger Sea between Iceland and the northern boundary of the NAC located at $53.15^{\circ} \mathrm{N}$. This estimation corresponds to the transport of the westward branch of the subpolar gyre that connects the Iceland Basin to the Irminger Sea. In the Iceland Basin, this branch flows southwestward along the eastern flank of the Reykjanes Ridge into a current called the East Reykjanes Ridge Current (ERRC). In the Irminger Sea, it flows northeastward along the western flank of the ridge into a current known as the Irminger Current (IC).

The ERRC, which has mostly been observed at the surface and subsurface and in studies based on drifters (Otto \& Van Aken, 1996; Reverdin et al., 2003; Valdimarsson \& Malmberg, 1999), upper-ocean repeated transects (Chafik et al., 2014; Childers et al., 2015; Knutsen et al., 2005), and numerical models (Treguier et al., 2005), is described as a narrow southwestward flow east of the Reykjanes Ridge. However, the idea of a continuous steady ERRC is inconsistent with some maps of surface velocities derived from satellite altimetry that shows a chaotic low-velocity southward flow east of the Reykjanes Ridge (Jakobsen et al., 2003). 
Along the repeated OVIDE transect, Daniault et al. (2016) provided an averaged view of the top-to-bottom vertical structure of the ERRC over $2002-2012$. At $58.8^{\circ} \mathrm{N}$, the ERRC was composed of a main quasibarotropic branch at $30.1^{\circ} \mathrm{W}$ and two surface and bottom intensified branches at $28.5^{\circ} \mathrm{W}$ and $29^{\circ} \mathrm{W}$, respectively, which together correspond to a $200-\mathrm{km}$ wide current east of the top of the Reykjanes Ridge. This averaged structure of the ERRC is similar to that previously documented by Sarafanov et al. (2012) for 2002-2008 at $59.5^{\circ} \mathrm{N}$. Nevertheless, the top-to-bottom structure of the ERRC was mainly documented in a narrow band of latitudes $\left(58-59.5^{\circ} \mathrm{N}\right)$ and was poorly observed south and north of it.

Along the Reykjanes Ridge, Petit, Mercier, et al. (2018) noted a significant densification of SubPolar Mode Water from $59-62^{\circ} \mathrm{N}$ to the $\mathrm{BFZ}$ at $57^{\circ} \mathrm{N}$. This evolution in density was attributed to their different connections to the northern branch of the NAC and to the subarctic front (Figure 1), respectively, through the cyclonic circulation of the Iceland Basin. Here we question the role of these inflows in the southward alongstream evolution of the ERRC properties prior to crossing the ridge.

By crossing the Reykjanes Ridge, the westward branch of the subpolar gyre joins the IC on the western flank of the ridge (Figure 1; Lavender et al., 2000; Ollitrault \& Colin de Verdière, 2014; Våge et al., 2011). Våge et al. (2011) defined the IC at $60^{\circ} \mathrm{N}$ as a two-branch surface-intensified northeastward flow of about 200 -km wide west of the top of the Reykjanes Ridge, with colder and fresher water masses in its western branch compared with its eastern branch. In their paper, they suggested that the IC is formed by the NAC from the Iceland Basin and that this explains the difference in hydrological properties between the two branches by the cyclonic circulation of the Iceland Basin described above. Such a pathway was also shown in the subsurface layer (floats at $27.5 \mathrm{~kg} / \mathrm{m}^{3}$ ) by Bower et al. (2002). However, there is evidence of connections between the Labrador Sea, the interior of the Irminger Sea, and the IC. Yashayaev et al. (2007) showed exchanges of Labrador Sea Water (LSW) between the Irminger Gyre and the IC along the repeated transatlantic section (AR7), and Lazarevich et al. (2004) showed that a RAFOS float drifting on the $27.5 \mathrm{~kg} / \mathrm{m}^{3}$ isopycnal joined the IC from the central Irminger Sea. In addition to the cross-ridge flow, interactions with the interior of the Irminger Sea should affect the circulation and properties of the IC. Here we address questions on the formation and along-stream connections of the IC with the ERRC and Irminger Gyre in order to discuss the influence of each basin.

In this article, we study the regional circulation in the Reykjanes Ridge region based on top-to-bottom transects along the Reykjanes Ridge and at three different latitudes across the ridge, conducted as part of the RREX project in 2015 (RREX2015 cruise, Figure 1 and supporting information, Figure S1). We focus our description on the connections between the ERRC and IC through the Reykjanes Ridge and their interactions with the basin interiors. A better understanding of the formation, evolution, and fate of these currents will greatly improve our knowledge on the water mass pathways from the eastern part of the subpolar gyre to the Irminger Sea and also on the impact of the Reykjanes Ridge on ocean circulation.

Section 2 presents the data and methods used for this study. We describe the horizontal and vertical structures of the along-ridge flows at three different latitudes along the Reykjanes Ridge in section 3. The latitudinal evolution of the hydrological properties of the along-ridge flows are also analyzed and compared with the properties of the cross-ridge flows. Section 4 discusses the circulation scheme deduced from our results and its comparison with previous findings. Finally, the results are summarized in section 5.

\section{Data and Methods}

\subsection{Data sets}

The RREX2015 cruise was conducted from 5 June to 10 July 2015 on the French R/V Thalassa. Measurements were taken at a total of 132 Conductivity Temperature Depth Oxygen $\left(\mathrm{CTDO}_{2}\right)$ stations during the RREX2015 cruise (Figure S1). Three sections were made perpendicular to the ridge axis and a fourth section extended from the Iceland shelf to $50^{\circ} \mathrm{N}$. The three zonal sections intersect the top of the Reykjanes Ridge at $24.7^{\circ} \mathrm{W} / 63^{\circ} \mathrm{N}, 31.3^{\circ} \mathrm{W} / 58.8^{\circ} \mathrm{N}$, and $34^{\circ} \mathrm{W} / 56.4^{\circ} \mathrm{N}$ and are referred to hereinafter as the northern, OVIDE, and southern sections, respectively. The OVIDE section repeats, from $27.2^{\circ} \mathrm{W}$ to $36.4^{\circ} \mathrm{W}$, the hydrographic line carried out as part of the OVIDE program (Mercier et al., 2015). These sections were designed to study the along-stream evolution of the ERRC and IC along the Reykjanes Ridge. The fourth latitudinal section, called ridge section, was used by Petit, Mercier, et al. (2018) to document and quantify the cross-ridge 
flows. The nominal station spacing was $30 \mathrm{~km}$ along the four sections and was reduced to $2 \mathrm{~km}$ at the BFZ $\left(57^{\circ} \mathrm{N}\right)$ and CGFZ $\left(52.5^{\circ} \mathrm{N}\right)$. To deploy moorings along the vessel track, the southern section was interrupted for $25 \mathrm{hr}$ after station $9\left(34^{\circ} \mathrm{W} / 56.4^{\circ} \mathrm{N}\right)$, the OVIDE section was interrupted for $18 \mathrm{hr}$ after station $38\left(29.3^{\circ} \mathrm{W} /\right.$ $\left.57.9^{\circ} \mathrm{N}\right)$, and the ridge section was interrupted for $34 \mathrm{hr}$ after station $83\left(31.3^{\circ} \mathrm{W} / 58.8^{\circ} \mathrm{N}\right)$. The ridge section was also interrupted for $22 \mathrm{hr}$ after station $101\left(33.6^{\circ} \mathrm{W} / 56.7^{\circ} \mathrm{N}\right)$ to carry out hydrographic measurements west of the BFZ main sill. These interruptions were not significant relative to the time spent recording measurements at each hydrographic station (about $4 \mathrm{hr}$ ). Nevertheless, the asynopticity related to the time necessary to realize the entire cruise was taken into account in the computation of error transports, as shown in Petit, Mercier, et al. (2018). Temperature, conductivity and dissolved oxygen were measured at each hydrographic station as a function of pressure using a Seabird Electronics $911+\mathrm{CTDO}_{2}$ probe mounted on a rosette of 28 bottles. The $\mathrm{CTDO}_{2}$ accuracies were $1 \mathrm{dbar}$ in pressure, $0.001{ }^{\circ} \mathrm{C}$ in temperature, 0.0025 in salinity and $1 \mu \mathrm{mol} \cdot \mathrm{kg}^{-1}$ in dissolved oxygen (Branellec \& Thierry, 2016). Along the ship track, a 12-kHz echosounder measured the bathymetry every $30 \mathrm{~s}$.

Velocity measurements were obtained using two Shipboard Acoustic Doppler Current Profiler, RD Instruments operating at $38 \mathrm{kHz}(\mathrm{OS} 38)$ and $150 \mathrm{kHz}$ (OS150). In this study, the OS150 data were used as additional data for the calibration of the OS38 velocities, and the OS38 data were used to constrain the geostrophic velocities (section 2.2). The bin size of the OS38 data was set at $24 \mathrm{~m}$, the maximum depth range was $1,300 \mathrm{~m}$, and the pinging rate $3 \mathrm{~s}$. Details on calibration of OS38 velocities can be found in Petit, Thierry, et al. (2018).

Surface geostrophic velocities were computed from the Merged Absolute Dynamic Topography of Ssalto/Duacs AVISO (Archiving, Validation and Interpretation of Satellite Oceanographic data center) altimeter products distributed by CMEMS (Copernicus Marine Environment Monitoring Service) on a $1 / 3^{\circ}$ grid.

Finally, Ekman transports were calculated at the location and time of measurement at each hydrographic station from the wind stress data of two global atmospheric reanalysis, ERA-Interim reanalysis (Dee et al., 2011) and NCEP/NCAR reanalysis (Kalnay et al., 1996).

\subsection{Absolute Geostrophic Velocities and Transport Estimates}

Geostrophic velocities between two adjacent $\mathrm{CTDO}_{2}$ stations were computed using the thermal wind equation and a reference level arbitrarily set at the surface. Dynamic heights needed for the thermal wind computation were themselves computed from temperature, salinity, and pressure. An absolute geostrophic field was estimated by adjusting the geostrophic field to S-ADCP velocity measurements and then adding a constant velocity correction to the geostrophic profile referenced to the surface (Gourcuff et al., 2011; Lherminier et al., 2007; Petit, Mercier, et al., 2018). As in Petit, Mercier, et al. (2018), the correction is the difference between the S-ADCP velocities horizontally averaged between two stations and the geostrophic velocities in a reference layer $L_{r e f}=600-1000 \mathrm{~m}$. At the ridge section, a single reference velocity was used over the BFZ and CGFZ (stations 96-101 and 119-122 in Figure S1, respectively) to cope with strong ageostrophic motions (see Petit, Mercier, et al., 2018). Geostrophic flows in the bottom triangles of the sloping topography were computed following Petit, Mercier, et al. (2018).

Transports across each section were computed as the sum of geostrophic and Ekman transports. The geostrophic transport was estimated by integrating geostrophic velocity over the horizontal distance of the pair of stations and over the vertical resolution $(1 \mathrm{~m})$ of the geostrophic velocity profile. Readers are invited to refer to Petit, Mercier, et al. (2018) for a presentation of the method used to compute errors for the transports. These errors take into account ageostrophic motions estimated from the differences between the S-ADCP and the geostrophic velocities.

In an attempt to close the volume budgets of the ERRC and IC transports, whose horizontal extensions are estimated in section 3.2 below, we divided the area into four boxes (Figure S1). Two boxes (one on each side of the ridge) were delimited by the northern section, the OVIDE section, and the ridge section. The box located east of the ridge section was closed by a line joining the stations at the eastern limits of the ERRC at the northern section and OVIDE section (stations 49 and 38, respectively), while that located west of the ridge section was closed by a line joining the stations at the western limits of the IC at the northern section and OVIDE section (stations 62 and 28, respectively). Similarly, two other boxes were delimited by the OVIDE section, the southern section, and the ridge section and were closed by lines joining the stations of 
Table 1

Criteria Used to Identify the Water Masses Along the Sections, as Defined by Petit, Mercier, et al. (2018)

\begin{tabular}{lclcc}
\hline Water mass & Potential density $\left(\mathrm{kg} / \mathrm{m}^{3}\right)$ & Salinity & Oxygen $(\mu \mathrm{mol} / \mathrm{kg})$ & Potential vorticity $(\mathrm{m} / \mathrm{s})$ \\
\hline NACW & $\sigma_{0}<27.52$ & $\mathrm{~S} \geq 34.94$ & & \\
SAW & $\sigma_{0}<27.52$ & $\mathrm{~S}<34.94$ & \\
SAIW & $27.52 \leq \sigma_{0}<27.71$ & $\mathrm{~S}<34.94$ & & \\
IW & $27.52 \leq \sigma_{0}<27.71$ & $\mathrm{~S} \geq 34.94$ & $\mathrm{O}_{2}<272$ & \\
SPMW & $27.52 \leq \sigma_{0}<27.71$ & $\mathrm{~S} \geq 34.94$ & $\mathrm{O}_{2} \geq 272$ & \\
LSW & $27.71 \leq \sigma_{0}<27.8$ & $\mathrm{~S}<34.94$ & \\
ISW & $27.71 \leq \sigma_{0}<27.8$ & $\mathrm{~S} \geq 34.94$ & \\
DSOW & $\sigma_{0} \geq 27.8$ & $\mathrm{~S}<34.94$ & \\
ISOW & $\sigma_{0} \geq 27.8$ & $\mathrm{~S} \geq 34.94$ & \\
\hline
\end{tabular}

Note. These criteria are based on limits of potential density $\left(\sigma_{0}\right)$, salinity $(\mathrm{S})$, dissolved oxygen concentration $(\mathrm{O} 2)$, and potential vorticity (PV), computed as $\mathrm{PV}=\frac{-f}{\rho} \frac{\partial \rho}{\partial z}$, where $\mathrm{f}$ is the Coriolis parameter, $\rho_{0}$ is the reference density, and $\rho$ is the potential density referenced to the mid-depth interval over which the vertical gradient of density is computed. Potential density limits are also given in Figure 2. NACW = North Atlantic Central Water; SAW = SubArctic Water; SAIW = SubArctic Intermediate Water; IW = Intermediate Water; SPMW = SubPolar Mode Water; LSW = Labrador Sea Water; ISW = Icelandic Slope Water; DSOW = Denmark Strait Overflow Water; ISOW = Iceland-Scotland Overflow Water.

the eastern limits of the ERRC (stations 38 and 2) and the western limits of the IC (stations 28 and 23). The volume budgets of these four boxes were estimated from the transports across the sections and by computing transports between the eastern limits of the ERRC and the western limits of the IC. For the latter two, horizontal gradients of dynamical heights referenced to the surface were computed between the ERRC endpoint stations and IC endpoint stations. The geostrophic velocities derived from these gradients were adjusted at the surface to the geostrophic velocities from AVISO that were averaged in space between the two endpoint stations and in time over the sampling of the associated sections. Transports were estimated by integrating these absolute geostrophic velocities over the distance between stations and the depth.

\subsection{Water Mass Characterization}

In this section, we define nine water masses by referring to Petit, Mercier, et al. (2018) and three layers in the vicinity of the Reykjanes Ridge. The criteria for the identification of these water masses are given in Table 1 and traced along the hydrographic sections in Figure 2. For $\sigma_{0} \leq 27.52 \mathrm{~kg} / \mathrm{m}^{3}$, one finds North Atlantic Central Water for salinity higher than 34.94 and SubArctic Water for salinity lower than 34.94 (Figure 2a). Between $27.52<\sigma_{0} \leq 27.71 \mathrm{~kg} / \mathrm{m}^{3}$, SubPolar Mode Water is defined by salinity and dissolved oxygen concentration (Figure $2 \mathrm{~b}$ ) higher than 34.94 and $272 \mu \mathrm{mol} / \mathrm{kg}$, respectively, and potential vorticity lower than $610^{-11} \mathrm{~m}^{-1} \mathrm{~s}^{-1}$; Intermediate Water is defined by salinity higher than 34.94 and dissolved oxygen concentration lower than $272 \mu \mathrm{mol} / \mathrm{kg}$; and SubArcticIntermediate Water is defined by salinity lower than 34.94. The density range $\sigma_{0}<27.71 \mathrm{~kg} / \mathrm{m}^{3}$ will be referred to hereinafter as the upper layer. Defined by 27.71 $\leq \sigma_{0}<27.8 \mathrm{~kg} / \mathrm{m}^{3}$, the middle layer contains LSW with salinity lower than 34.94 and Icelandic Slope Water with salinity higher than 34.94 . Finally, the deep layer, defined by $\sigma_{0} \geq 27.8 \mathrm{~kg} / \mathrm{m}^{3}$, encompasses IcelandScotland Overflow Water (ISOW) with salinity higher than 34.94 and, in the Irminger Sea, Denmark Strait Overflow Water with salinity lower than 34.94, which coincides with isopycnal $27.88 \mathrm{~kg} / \mathrm{m}^{3}$ (Sarafanov et al., 2012). Readers are invited to refer to Figure 3 of Petit, Mercier, et al. (2018) for the identification of these water masses along the ridge section.

\section{Results: Connections Between the Iceland Basin and Irminger Sea}

\subsection{Horizontal and Vertical Structures of the Along-Ridge Currents}

Figure 3 shows the absolute geostrophic velocities across the northern section, OVIDE section, and southern section. East of the Reykjanes Ridge, the horizontal and vertical structures of the southward flows change strongly from the northern to the southern section. Across the northern section, the southward flow is divided in three bottom-intensified branches localized, from west to east, at 0-75 km, $+100-240 \mathrm{~km}$, and $+250-325 \mathrm{~km}$. The latter lies only in the middle and deep layers. Northward flows are observed between these branches and at the eastern end of the section. Across the OVIDE section, the southward flow is divided into two branches separated by a surface-intensified northward flow at $+150 \mathrm{~km}$. The first branch 

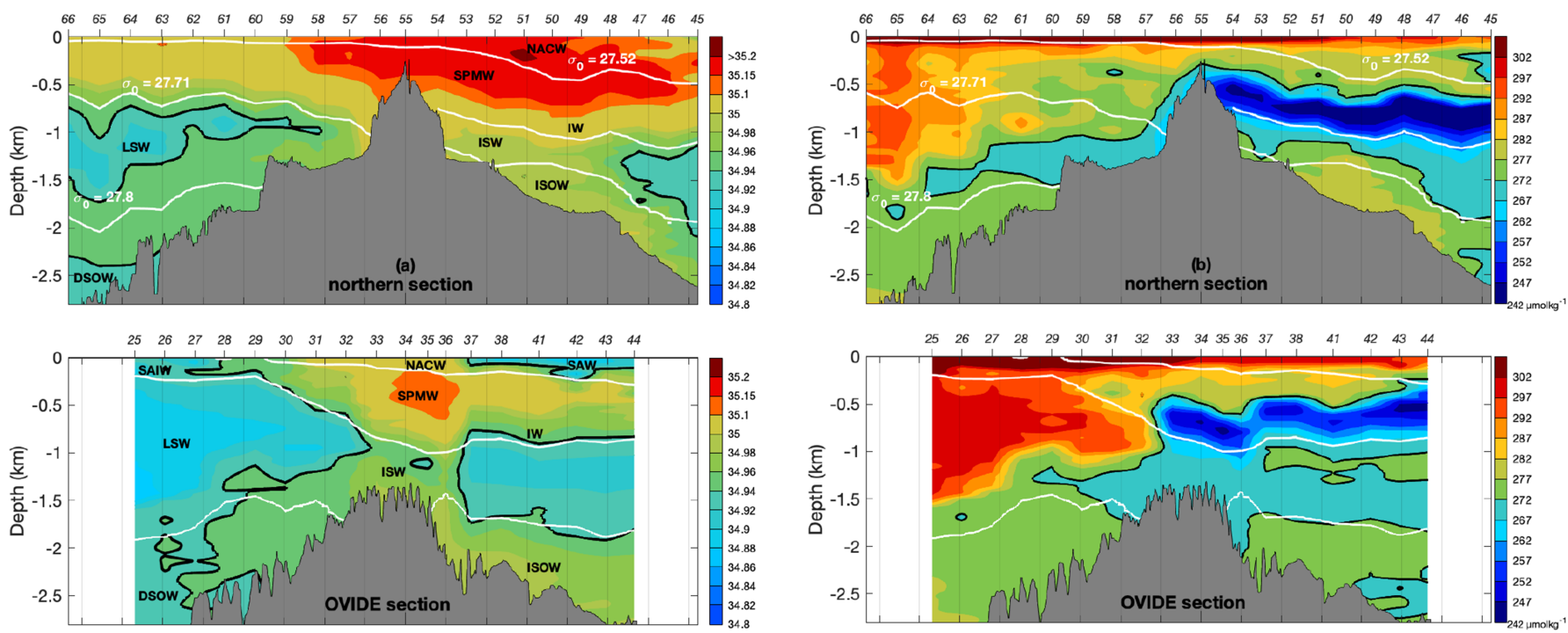

$\begin{array}{llllllllllllllll}24 & 23 & 22 & 21 & 20 & 15 & 14 & 9 & 8 & 7 & 6 & 5 & 4 & 3 & 2\end{array}$
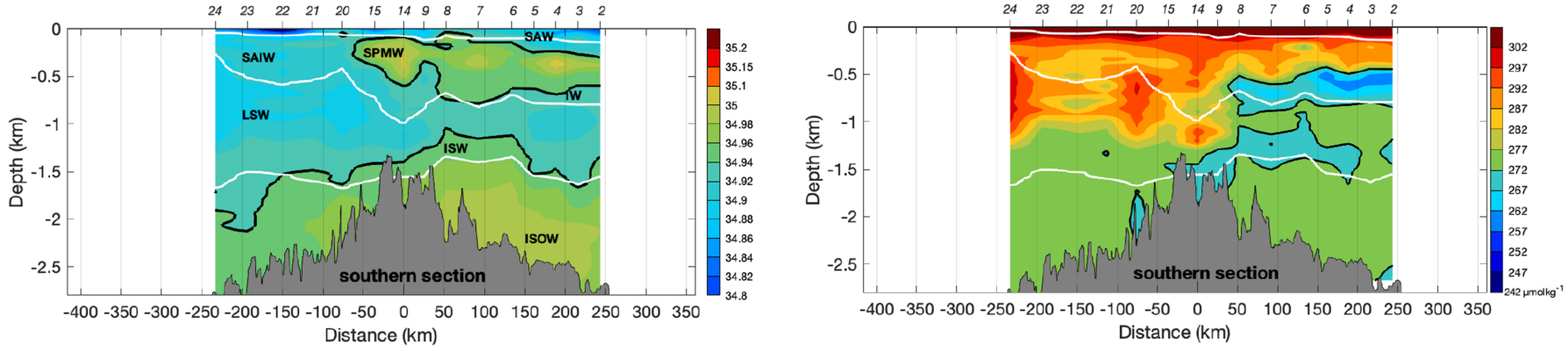

Figure 2. (a, b) Salinity and dissolved oxygen concentration ( $\mu \mathrm{mol} / \mathrm{kg}$ ) along the northern (upper panels), OVIDE (middle panels), and southern (lower panels) sections based on $\mathrm{CTDO}_{2}$ data. White lines show the potential density anomalies $\sigma_{0}=27.52,27.71$, and $27.8 \mathrm{~kg} / \mathrm{m}^{3}$. Bathymetry from the ship survey is shown in grey. Locations of the hydrographic stations are indicated on the top axis. The bold black lines show the 34.94 isohaline in panel (a) and the $272 \mu \mathrm{mol} / \mathrm{kg}$ isoline in panel (b). They outline the criteria used for the identification of water masses in Table 1, where isopycnal lines do not suffice.

is surface-intensified $(>0.1 \mathrm{~m} / \mathrm{s})$ at $0-100 \mathrm{~km}$ and the second branch is bottom-intensified with a core at $+225 \mathrm{~km}$. Across the southern section, the southward flow is divided into three main branches: a surfaceintensified branch at $0-50 \mathrm{~km}$ that contains no southward core in its deep layer, a bottom-intensified middle branch with a core at $+150 \mathrm{~km}$ that lies in the middle and deep layers, and a bottom-intensified branch at $+200-250 \mathrm{~km}$. To summarize, southward bottom-intensified branches are found east of +100 $\mathrm{km}$ at the three sections, while the vertical structure of the branches localized west of $+100 \mathrm{~km}$ varies between the three sections. This branch is bottom-intensified at the northern section and surfaceintensified at the OVIDE section and at the southern section.

To the west of the Reykjanes Ridge on the three sections, the flow is divided into two northward surfaceintensified branches bounded to the west by southward surface-intensified flows, even though the southward flow was not completely sampled at the southern section (Figure 3). The two northward branches are localized at $-250-0 \mathrm{~km}$ at the northern section, with similar surface velocities in both branches $(0.08$ $\mathrm{m} / \mathrm{s})$. At the OVIDE section, the two northward branches are localized at $-200-0 \mathrm{~km}$, with larger surface velocities in the eastern branch $(0.21 \mathrm{~m} / \mathrm{s})$ than in the western branch $(0.11 \mathrm{~m} / \mathrm{s})$. Finally, two northward branches are localized at $-50-0 \mathrm{~km}$ and at $-200-100 \mathrm{~km}$ at the southern section and are separated by a southward bottom-intensified flow at $-100-50 \mathrm{~km}$.

\subsection{Volume Budget of the Along-Ridge Currents}

According to Daniault et al. (2016), the time-averaged ERRC comprises southward flows of about 200-km wide east of the top of the Reykjanes Ridge. Likewise, Våge et al. (2011) showed that the time-averaged IC 

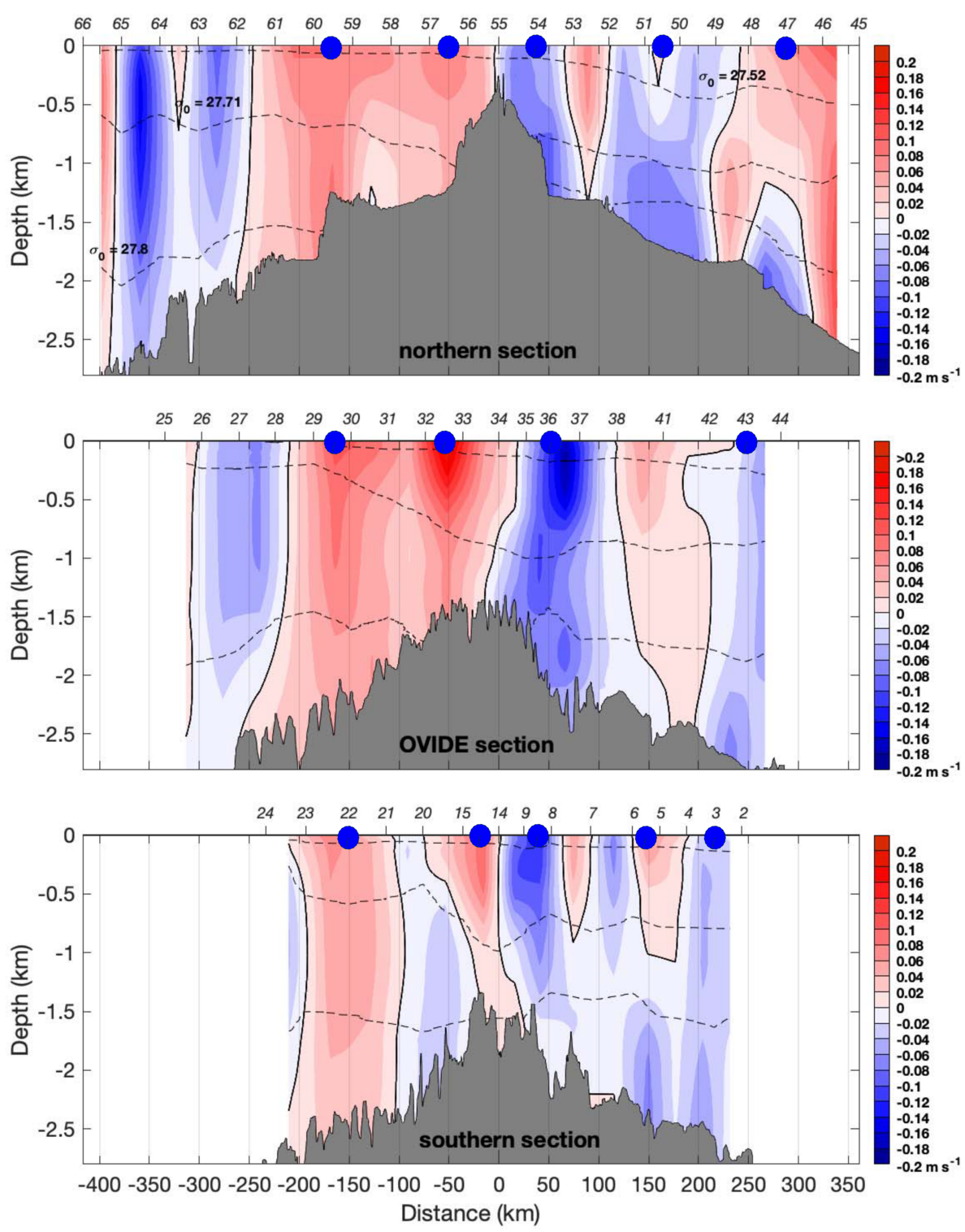

Figure 3. Geostrophic velocity along the northern (upper panel), OVIDE (middle panel), and southern (lower panel) sections $(\mathrm{m} / \mathrm{s})$. Positive values correspond to northward velocities. The bold black line traces the 0 isotach. Dashed black lines indicate the potential density $\sigma_{0}=27.52,27.71$, and $27.8 \mathrm{~kg} / \mathrm{m}^{3}$. Bathymetry from the ship survey is shown in grey.

Locations of the hydrographic stations are indicated on the top axis. Blue dots indicate the cores for the main southward flows in the Iceland Basin and northward flows in the Irminger Sea.

comprises two surface-intensified northward flows within about $200 \mathrm{~km}$ west of the top of the Reykjanes Ridge. To identify the ERRC and IC in our data set, we first computed vertically integrated top-to-bottom transports from the geostrophic velocities (Figure 3) and cumulated these transports from the top of the Reykjanes Ridge (Figure 4). The outer edges of the ERRC and IC were defined as the positions of the respective minimum and maximum of the cumulative transport curves at about $200 \mathrm{~km}$ east and west of the top of the Reykjanes Ridge.

On the eastern side of the ridge, the cumulative transport curves reach their minima at $+220 \mathrm{~km}$ (station 49) for the northern section, $+120 \mathrm{~km}$ (station 38 ) for the OVIDE section, and $+245 \mathrm{~km}$ (station 2) for the southern section. Based on these limits, the ERRC transports and associated errors (section 2) were estimated at $-10.6 \pm 0.9 \mathrm{~Sv}$ at the northern section, $-13.8 \pm 0.6 \mathrm{~Sv}$ at the OVIDE section, and $-13.0 \pm 1.2 \mathrm{~Sv}$ at the 

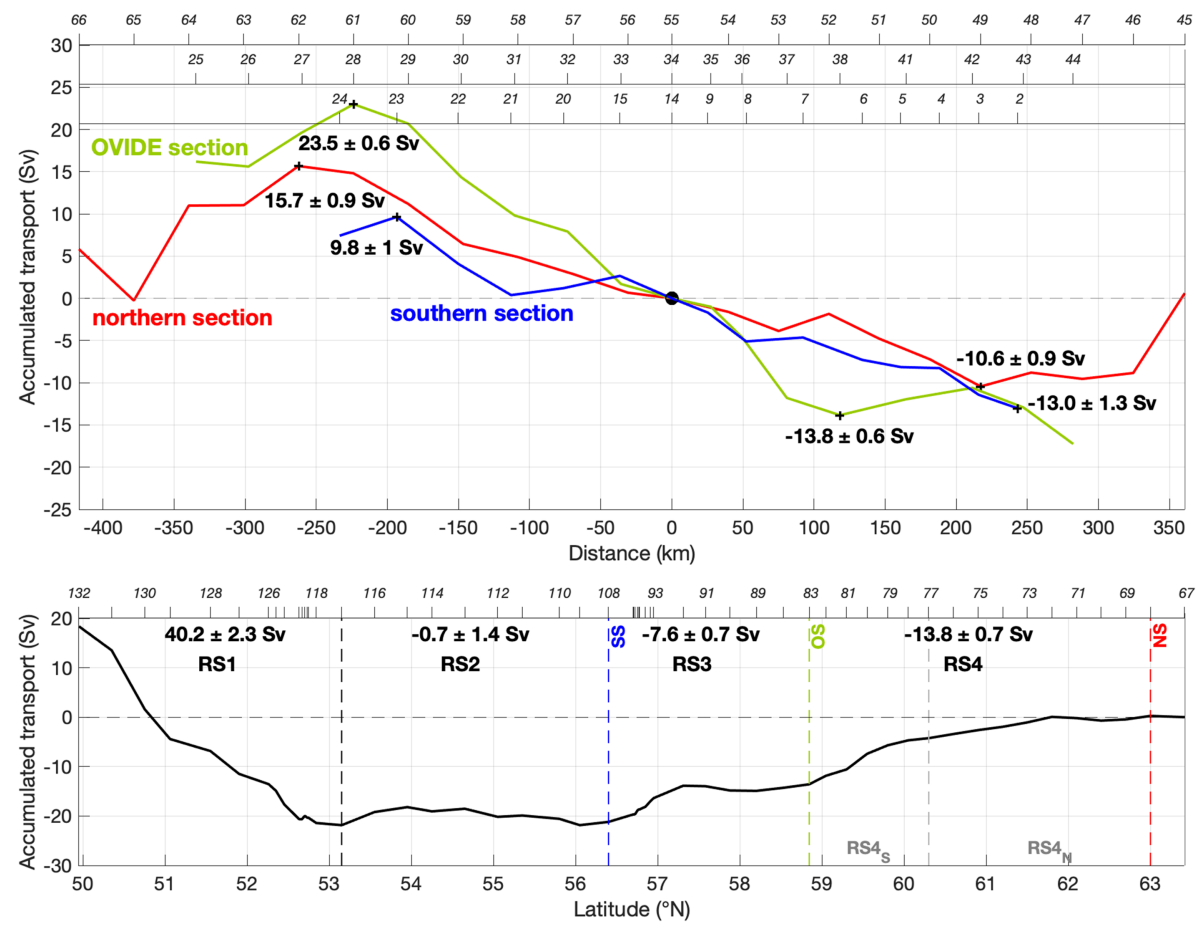

Figure 4. (Upper panel) Top-to-bottom vertically integrated transport (Sv) along the northern (stations 45 to 66, red line), OVIDE (stations 25 to 44, green line) and southern (stations 2 to 24, blue line) sections cumulated from the top of the Reykjanes Ridge (black spot at $0 \mathrm{~km}$ ) eastward toward the Iceland Basin and westward toward the Irminger Sea. Black crosses indicate the outer edges of the ERRC and IC, and are the outer limits used for the ERRC and IC transport computations across each section. (Lower panel) Top-to-bottom vertically integrated transport (Sv) along the ridge section from Petit, Mercier, et al. (2018). Each zonal section (northern section: NS, OVIDE section: OS, southern section: SS) is delimited in the lower panel by vertical black and gray lines, with the limits of regions RS2, RS3 and RS4 different from those taken by Petit, Mercier, et al. (2018). The vertical black line at $53.15^{\circ} \mathrm{N}$ delimits the NAC northern boundary as defined by Petit, Mercier, et al. (2018). In each panel, locations of the hydrographic stations are shown on the top axis. Northward and eastward (southward and westward) transports are positive (negative).

southern section. On the western side of the ridge, the cumulative transport curves reach their maxima at $-260 \mathrm{~km}$ (station 62) for the northern section, $-225 \mathrm{~km}$ (station 28) for the OVIDE section, and $-195 \mathrm{~km}$ (station 23) for the southern section. Given these limits, the IC transports were estimated at $15.7 \pm 0.9 \mathrm{~Sv}$ at the northern section, $23.5 \pm 0.6 \mathrm{~Sv}$ at the OVIDE section, and $9.8 \pm 1 \mathrm{~Sv}$ at the southern section. The two branches that compose the IC will be referred to hereinafter as the western and eastern IC branches. These branches are separated by the pair of stations 57-58 at the northern section, 31-32 at the OVIDE section, and 20-21 at the southern section (Figure 3). The surface velocities (Figure 5 and supporting information, Figure S2) confirm that the flows beyond the outer edges of these currents were linked to northward flowing NAC branches or to mesoscale structures in the Iceland Basin and Irminger Sea not associated with the ERRC or IC and that the southern section covers the overall top-to-bottom southward ERRC.

ERRC and IC transports vary in latitude. The top-to-bottom IC transport peaks on the OVIDE section (Figures 4 and 6) following the evolution of the middle and deep layers (Table 2). The transport for the upper layer peaks on the northern section. The ERRC transport increases from the northern to the OVIDE section. It remains nearly constant southward between the OVIDE and southern sections due to a decrease in transport in the upper and middle layers, balanced by a transport increase in the deep layer (Table 2). By combining the ERRC and IC transports with the cross-ridge transports estimated across the ridge section (Figure 4), we built a volume budget of these currents in the four boxes defined in section 2.2 (Figures 6 and S1). This volume budget reveals that the latitudinal variations of the ERRC and IC transports cannot be explained by the cross-ridge transports alone (Figure 6) and that connections between these along-ridge currents and the interior of the Iceland Basin and Irminger Sea also need to be considered. 


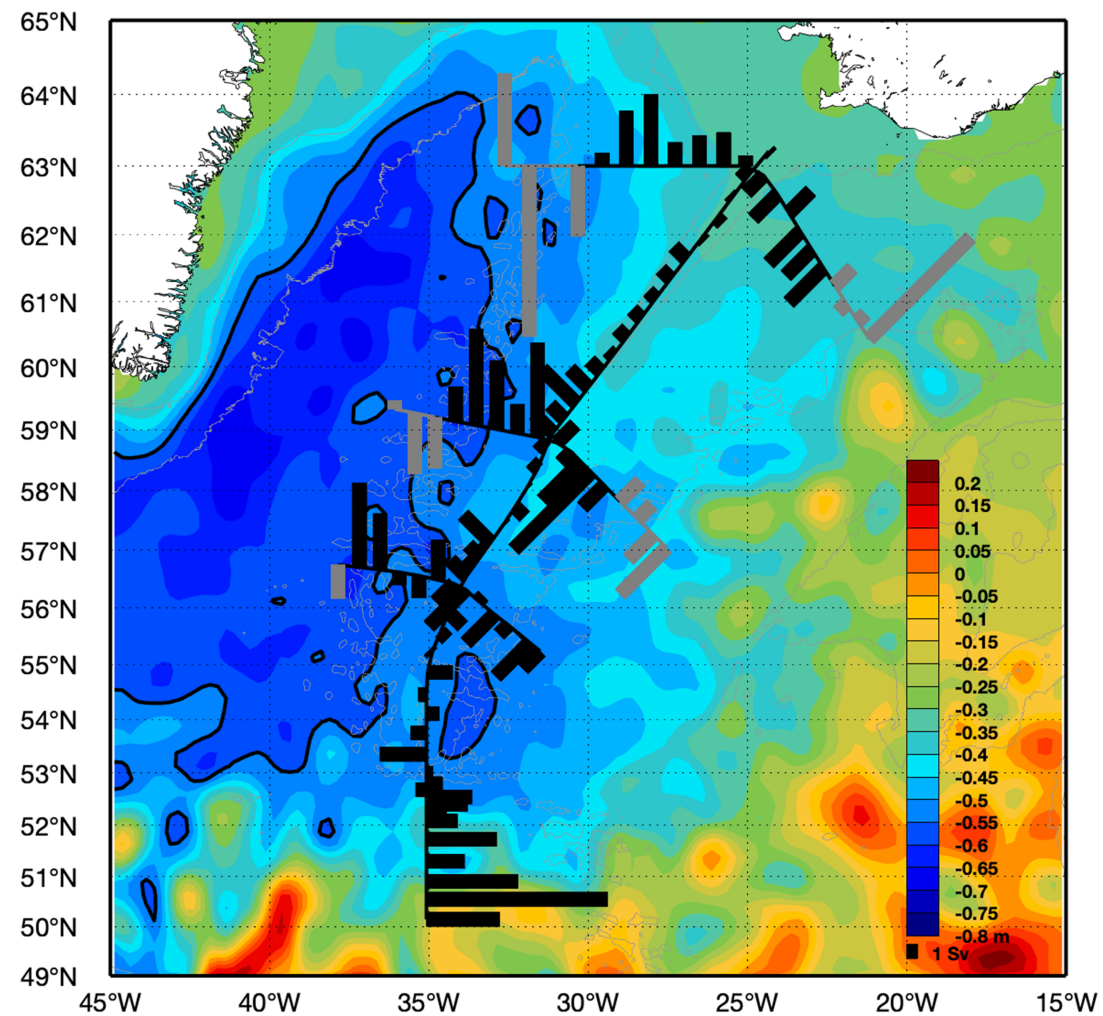

Figure 5. Absolute dynamic topography $(\mathrm{m})$ from AVISO, time-averaged between 10 and 23 June 2015, which corresponds to the time required to sample the three zonal sections during the RREX2015 cruise. The contour $-0.55 \mathrm{~m}$ is traced by a bold black line to show the inflows from the center of the Labrador Sea that join the western branch of the IC. Black bars represent the top-to-bottom vertically integrated transports (Sv) perpendicular to the four sections at each pair of stations. Grey bars indicate the transports not associated with the ERRC or IC at the northern, OVIDE, and southern sections. Bathymetries $-1000 \mathrm{~m}$ and $-2500 \mathrm{~m}$ are plotted in grey.

Estimates of the amount of water joining or leaving the IC and ERRC were first obtained as residuals of the sum of the volume transports across the three sections forming each of the four boxes and for which we had transport estimates from closely spaced hydrographic stations (Figure 6). The budget residual shows that an input from the Iceland Basin is necessary to close the volume budget of the ERRC. This input amounts to 17 Sv between the northern section and the OVIDE section (red box) and to $6.8 \mathrm{~Sv}$ between the OVIDE section and the southern section (green box). Similarly, the volume budget shows that a 6.1-Sv input from the Irminger Sea is required to feed the IC between the southern section and the OVIDE section (blue box), while an 21.6-Sv output toward the Irminger Sea is necessary to explain the decrease in IC transport between the OVIDE and northern sections (orange box). Another quantification of these inputs was obtained by computing the geostrophic transport between the eastern (western) limit of the ERRC (IC) at the northern section and at the OVIDE section for the red (orange) box and between the OVIDE section and the southern section for the green (blue) box (see section 2.2 and Figure 6). With differences less than $2 \mathrm{~Sv}$, the agreement between the two estimates is remarkable considering not only the presence of mesoscale coherent structures that were not entirely resolved by the smoothed surface velocities from AVISO (Figure S2) but also the data asynopticity (section 2.1).

\subsection{Estimation of the Circulation Based on Hydrography and Volume Budget}

Based on the results of sections 3.1 and 3.2, we will now discuss elements of the circulation in the vicinity of the Reykjanes Ridge and build circulation schemes for the upper, middle, and deep layers (Figure 7). The geostrophic transports of the ERRC, cross-ridge flows, and IC branches are indicated for each layer at each section (yellow boxes in Figure 7). The circulation schemes include inflows from and outflows to the basin interiors at the eastern and western edges of the ERRC and IC, respectively, as shown in Figure 6. The associated transports are those required to close the volume budgets (blue boxes in Figure 7). For completeness, 


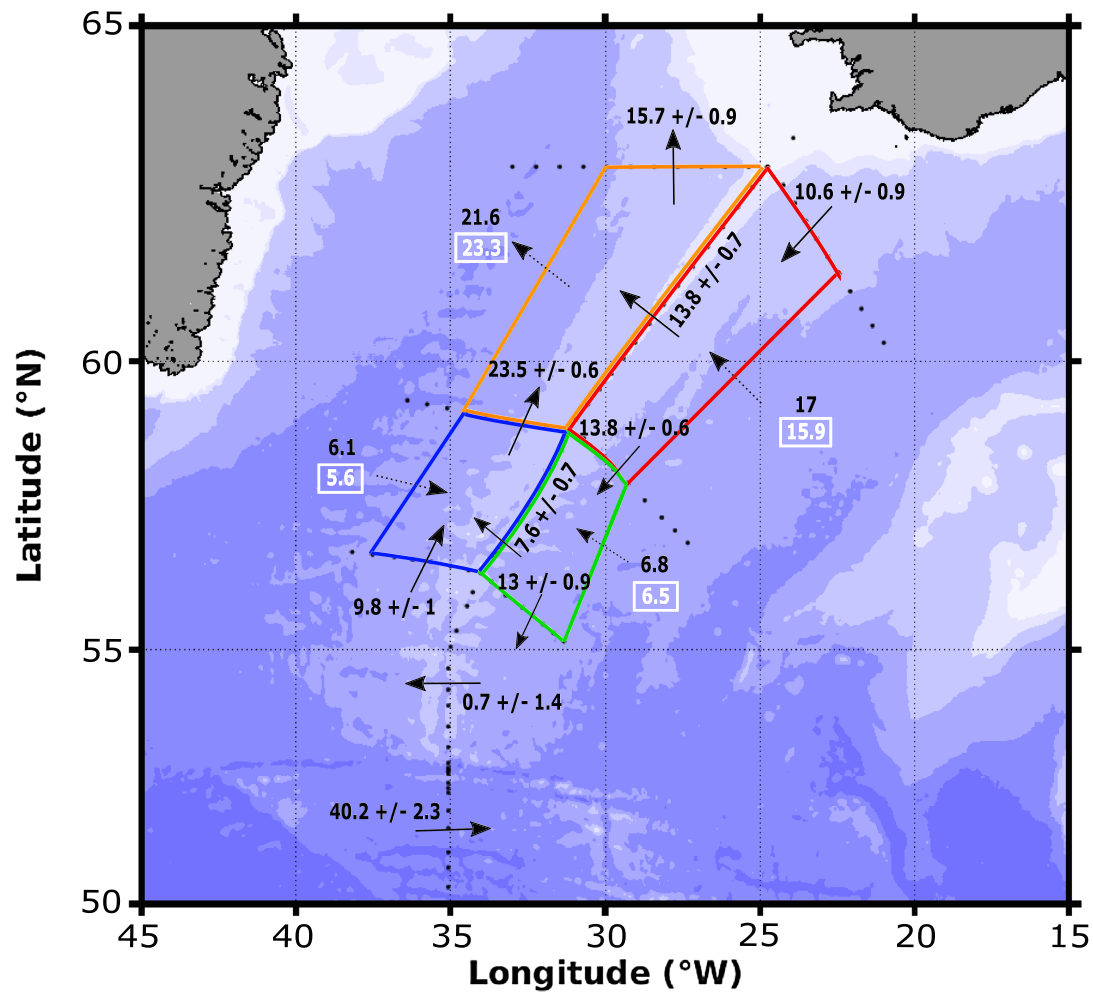

Figure 6. Schematic showing the top-to-bottom vertically integrated transports (Sv) of the ERRC and IC in each box delimited by the northern, OVIDE, southern, and ridge sections (plain arrows). In each box are indicated the associated input/output transports estimated to balance the volume budget of the box (dashed arrows, black numbers). White numbers are the effective input/output transports computed between the last eastern and western hydrographic stations of the ERRC and IC, respectively.

these regional circulation patterns were then imbedded in the large-scale circulation scheme of Figure 1. Some elements of the circulation were derived, as detailed below, from an analysis of $\theta / \mathrm{S}$ properties of the ERRC, the cross-ridge flows, and the IC branches (Figures 8-11). These $\theta / \mathrm{S}$ curves were obtained by selecting the potential vertical temperature $(\theta)$ and salinity $(S)$ profiles belonging to a given current branch, then averaging along isopycnals.

\subsubsection{The ERRC, Combination of Distinct Circulation Flows}

The horizontal and vertical structures of the ERRC changed greatly from the northern to the southern section (Figure 3). The ERRC velocities were bottom-intensified at the northern section. Due to the bathymetry that blocked the middle layer north of about $60^{\circ} \mathrm{N}$ and the deep layer north of the BFZ (Petit, Mercier, et al., 2018), the cross-ridge flow (7.3 Sv) mainly occurred in the upper layer $(7.1 \mathrm{~Sv})$ between $60.3^{\circ} \mathrm{N}$ and $63^{\circ} \mathrm{N}$ (region $\mathrm{RS} 4_{\mathrm{N}}$ along the ridge) and both in the upper and middle layers between $60.3^{\circ} \mathrm{N}$ and the OVIDE section (4.3 and 2.2 Sv in region RS4 $4_{S}$, respectively). Between the northern section and the OVIDE section,

Table 2

Transports (Sv) of the ERRC and IC for Each Zonal Section and for Each Layer (Upper Layer: $\sigma_{0}<27.71 \mathrm{~kg} / \mathrm{m}^{3} ;$ Middle Layer : $27.71 \leq \sigma_{0}<27.8 \mathrm{~kg} / \mathrm{m}^{3} ;$ Deep Layer: $\sigma_{0}$ $\left.\geq 27.8 \mathrm{~kg} / \mathrm{m}^{3}\right)$

\begin{tabular}{|c|c|c|c|c|c|c|}
\hline & \multicolumn{2}{|c|}{ Southern section } & \multicolumn{2}{|c|}{ OVIDE section } & \multicolumn{2}{|c|}{ Northern section } \\
\hline & IC (st. 14-23) & ERRC (st. 2-14) & IC (st. 28-34) & ERRC (st. 34-38) & IC (st. 55-62) & ERRC (st. 49-55) \\
\hline Upper layer & 4.7 & -5.3 & 9.2 & -7.2 & 9.5 & -5.2 \\
\hline Middle layer & 2.6 & -3.5 & 10.3 & -4 & 5.2 & -2.6 \\
\hline Deep layer & 2.5 & -4.2 & 4 & -2.6 & 1 & -2.8 \\
\hline
\end{tabular}

Note. ERRC $=$ East Reykjanes Ridge Current; $\mathrm{IC}=$ Irminger Current; st. = station. 

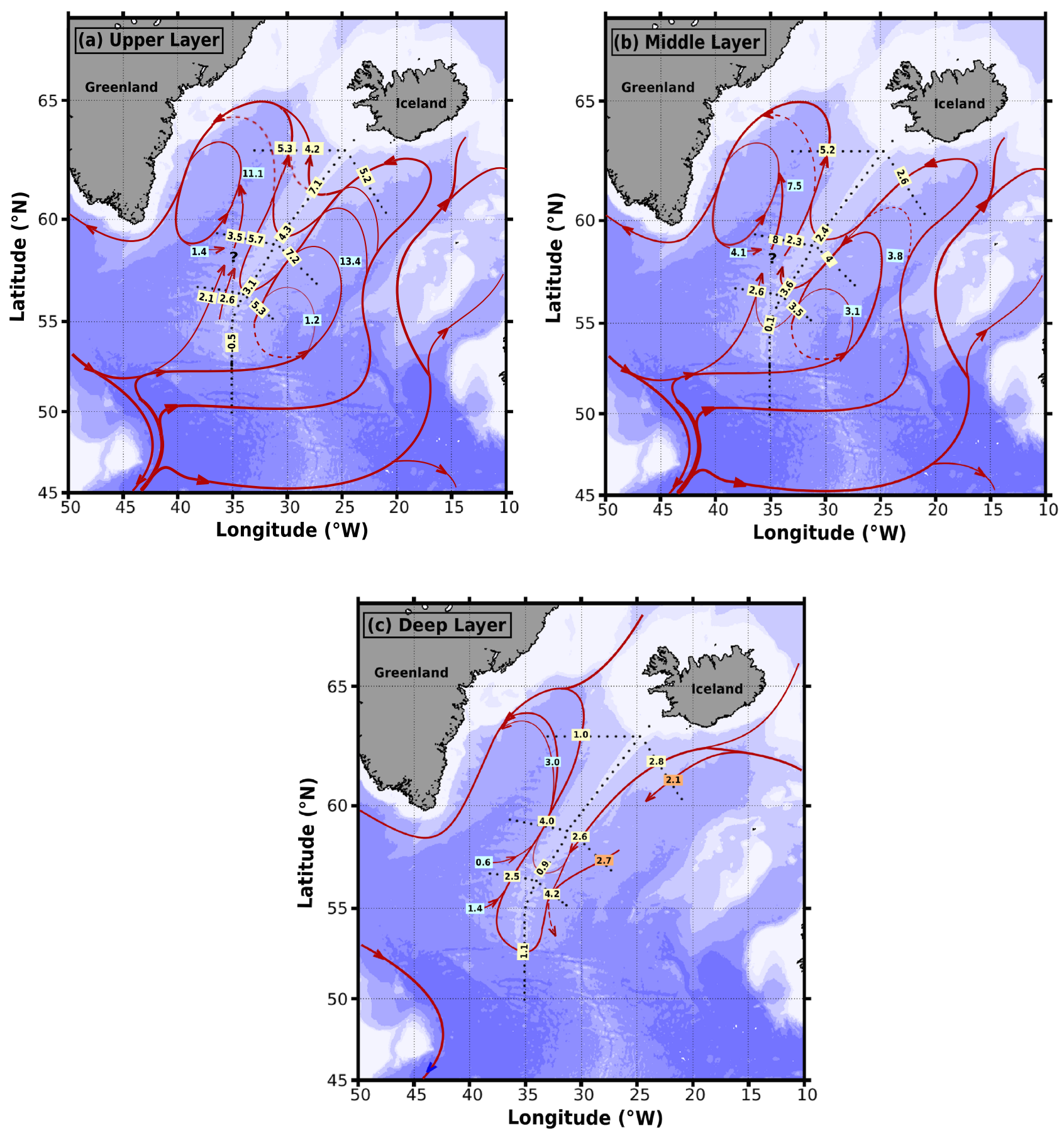

Figure 7. Schematic of the large-scale circulation of (a) the upper $\left(\sigma_{0}<27.71 \mathrm{~kg} / \mathrm{m}^{3}\right)$, (b) middle $\left(27.71 \leq \sigma_{0}<27.8 \mathrm{~kg} / \mathrm{m}^{3}\right)$, and $(\mathrm{c})$ deep $\left(\sigma_{0} \geq 27.8 \mathrm{~kg} / \mathrm{m}^{3}\right)$ layers deduced from our results in the vicinity of the Reykjanes Ridge and inserted in the scheme from Daniault et al. (2016) shown in Figure 1. Dashed arrows and question marks indicate the uncertain pathways. Locations of the hydrographic stations measured along the four sections during the RREX2015 cruise are overlaid (black dots). (a, b, c) Transports (Sv) of each layer in the ERRC, IC, and cross-ridge flows at the sections are indicated in yellow boxes. On panel (c), transports (Sv) for the ISOW cores that do not belong to the ERRC are indicated in orange boxes. Transports (Sv) required to close the volume budgets in each layer (Figure 6) are indicated in blue boxes. Positive transports follow the arrow directions; the negative transport value of the cross-ridge flow ( $-0.5 \mathrm{~Sv})$ in the upper layer is associated with a net eastward flow. Bathymetry is plotted in blue with deeper shades at 500, 1,000, and every 1,000 $\mathrm{m}$ below 1,000 m.

strong inflows of 13.4 Sv in the upper layer and of 3.8 Sv in the middle layer joined the ERRC (Figure 7). These inflows, which were not balanced by the cross-ridge flows, resulted in an increase in the ERRC transport (Table 3) and caused its surface intensification (Figure 3) between the northern section and the 


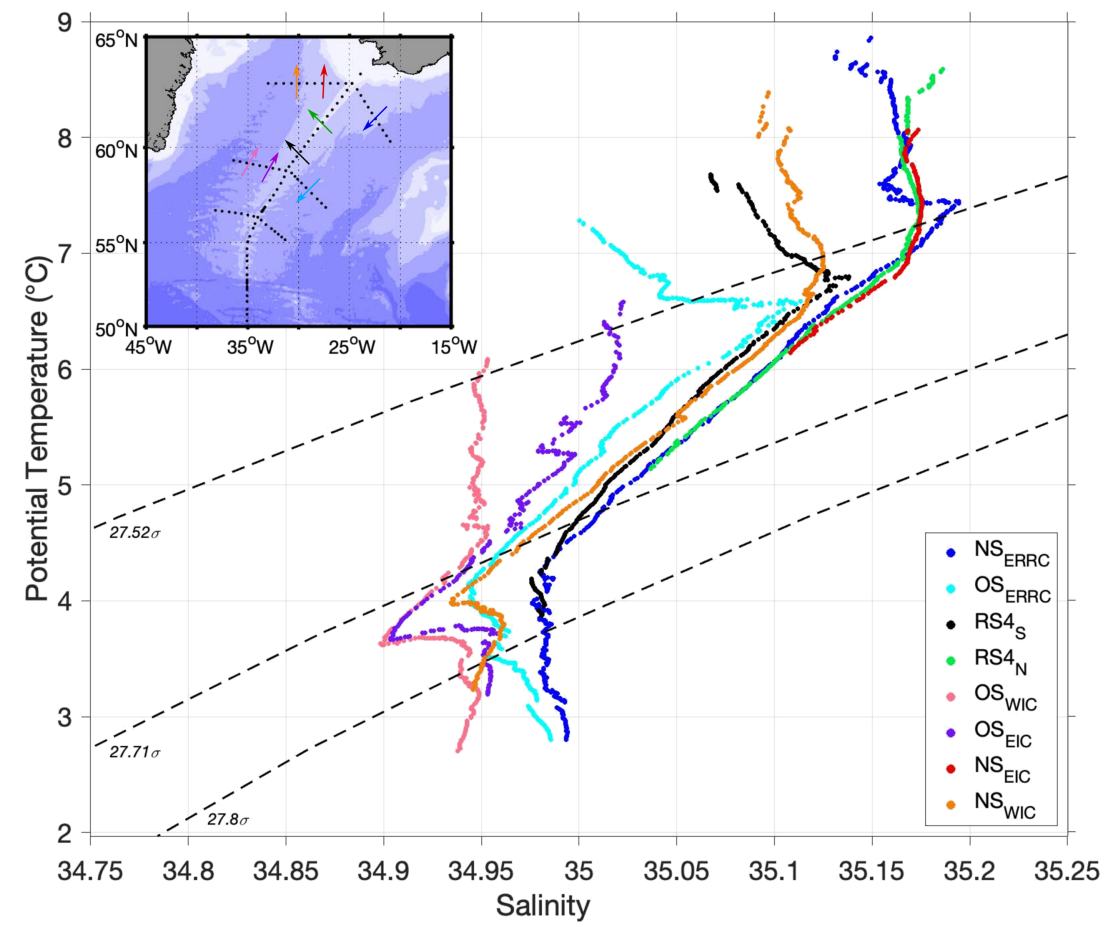

Figure 8. $\theta / \mathrm{S}$ diagram displaying hydrographic profiles averaged along isopycnals: for the ERRC at the northern $\left(\mathrm{NS}_{\mathrm{ERRC}}\right.$, blue dots) and OVIDE (OS $\mathrm{ERRC}_{\mathrm{E}}$, cyan dots) sections; for the eastern and western branches of the IC at the northern ( $\mathrm{NS}_{\mathrm{EIC}}$, red dots and NS $\mathrm{WIC}$, orange dots) and OVIDE (OS $\mathrm{S}_{\mathrm{EIC}}$, purple dots and OS $\mathrm{WIC}_{\mathrm{WI}}$, pink dots) sections; and across the ridge section at $58.8-60^{\circ} \mathrm{N}\left(\mathrm{RS} 4_{\mathrm{S}}\right.$, black dots) and $60-63^{\circ} \mathrm{N}\left(\mathrm{RS}_{\mathrm{N}}\right.$, green dots). The dashed black lines indicate isopycnals $\sigma_{0}=27.52,27.71$, and $27.8 \mathrm{~kg} / \mathrm{m}^{3}$. (Inserted map) bathymetric map of the North Atlantic with a $1,000-\mathrm{m}$ spacing (darker blue is deeper), giving the color code of the $\theta / \mathrm{S}$ diagram with the stations in black dots.

OVIDE section. In the deep layer, the flow decreased by $0.2 \mathrm{~Sv}$ between the northern section and the OVIDE section, suggesting some recirculation in the Iceland Basin or diapycnal mixing between the middle and deep layers.

The ERRC intensity slightly decreased from the OVIDE section to the southern section (Table 2). In the upper and middle layers, the ERRC both feeds the westward cross-ridge flow (3.1 and 3.6 Sv, respectively, Figure 7), mainly at the BFZ (Petit, Mercier, et al., 2018), and is reinforced by significant inflows from the interior of the Iceland Basin (1.2 Sv in the upper layer and 3.1 Sv in the middle layer). In the deep layer, one third $(0.9 \mathrm{~Sv})$ of the flow observed at the OVIDE section in the ERRC reaches the Irminger Sea as a cross-ridge flow, mainly through the BFZ (Figure 7). The rest crosses the southern section after being joined by the eastern core of ISOW at the OVIDE section $(2.7 \mathrm{~Sv})$.

The comparison of the $\theta /$ S profiles (Figure $8, \mathrm{NS}_{\text {ERRC }}$ and $\mathrm{RS}_{\mathrm{S}}$, respectively) reveals that the cross-ridge flow in region $\mathrm{RS}_{\mathrm{N}}$ is mainly fed by the ERRC from the northern section $(5.2 \mathrm{~Sv})$. The inflows from the center of the Iceland Basin north of the OVIDE section thus feed the cross-ridge flow in region $\mathrm{RS}_{\mathrm{S}}$ as well as the ERRC at the OVIDE section. As the surface and intermediate water masses in the center of the Iceland Basin are relatively cool and fresh compared with those at the periphery of the Iceland Basin (de Boisséson, 2010), they cause the isopycnal freshening and cooling of the ERRC observed between the northern and OVIDE sections (Figure 8, $\mathrm{NS}_{\mathrm{ERRC}}$ and $\mathrm{OS}_{\mathrm{ERRC}}$, respectively). For the same reason, the ERRC continues to freshen and to cool (Figure 9, $\mathrm{OS}_{\mathrm{ERRC}}$ and $\mathrm{SS}_{\mathrm{ERRC}}$, respectively) between the OVIDE section and the southern section.

In light of these results, we conclude that the ERRC did not flow continuously into one top-to-bottom current from the northern to the southern section but was composed of distinct southward flows joining and leaving the ERRC as influenced by the bathymetry of the Reykjanes Ridge and by its connections with the interior of the Iceland Basin. The convergence of these flows at the OVIDE section leads to a barotropic 

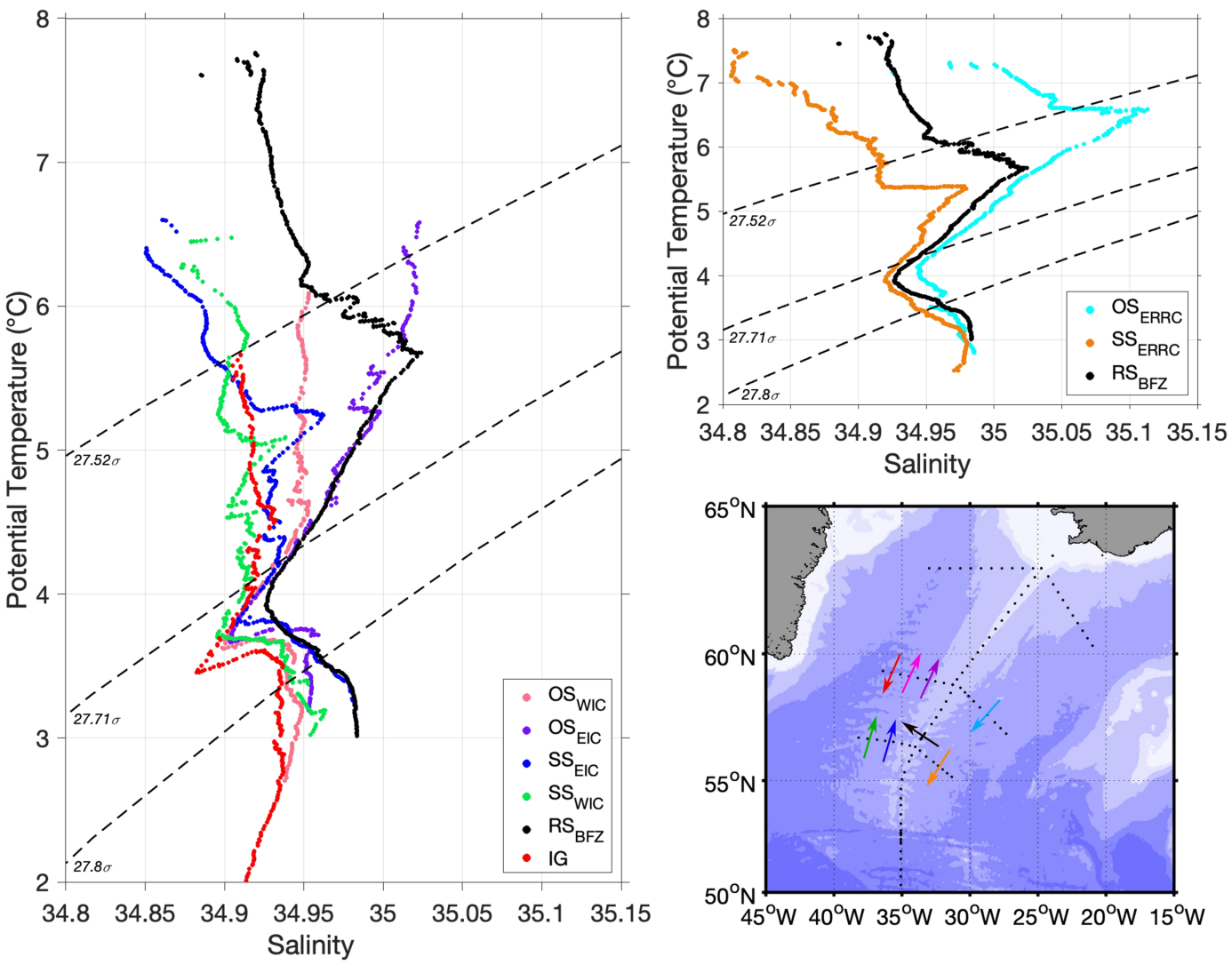

Figure 9. (Left panel) $\theta / \mathrm{S}$ diagram displaying hydrographic profiles averaged along isopycnals of the eastern and western branches of the IC at the southern (SS $\mathrm{EIC}_{\text {, }}$ blue dots and $\mathrm{SS}_{\mathrm{WIC}}$, green dots) and OVIDE (OS $\mathrm{OIC}_{\mathrm{EC}}$, purple dots and $\mathrm{OS}_{\mathrm{WIC}}$, pink dots) sections; across the ridge section at the $\mathrm{BFZ}$ (RS3 $3_{\mathrm{BFZ}}$ at $56.1-57.3^{\circ} \mathrm{N}$, black dots), where the westward cross-ridge flow was intensified (Petit, Mercier, et al., 2018); and of the southward flow at the western edge of the OVIDE section $\left(-300-200 \mathrm{~km}\right.$ in Figure 3) associated with a recirculation of the Irminger Gyre (IG, red dots). The dashed black lines indicate isopycnals $\sigma_{0}=27.52,27.71$, and 27.8 $\mathrm{kg} / \mathrm{m}^{3}$ that trace the limits of the upper and middle layers. (Upper right panel) same as for the left panel for RS3 ${ }_{\mathrm{BFZ}}$ (black dots) and for the ERRC at the OVIDE

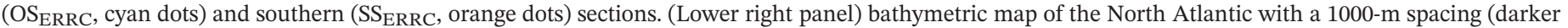
blue is deeper) and indicating the color code of the $\theta / \mathrm{S}$ diagram with the stations in black dots.

structure of the ERRC there. Relatively fresh and cold inflows from the Iceland Basin renewed the ERRC water masses in the upper and middle layers between the northern section and the southern section while warmer and saltier water masses crossed the Reykjanes Ridge and joined the IC at these latitudes.

\subsubsection{The IC, Two Branches with Different Origins and Pathways}

We will now focus on the origin and northward pathways of the IC along the western side of the Reykjanes Ridge (Figure 7). At the southern section, the transports of the western and eastern branches of the IC in the upper layer were 2.1 and $2.6 \mathrm{~Sv}$, respectively. The origins of these branches can be inferred from their $\theta / \mathrm{S}$ profiles. In the upper layer, the $\theta / S$ profile for the eastern branch is warmer and saltier than that for the western branch (Figure 10, $\mathrm{SS}_{\mathrm{EIC}}$ and $\mathrm{SS}_{\mathrm{WIC}}$, respectively) and is similar to that for the cross-ridge flow between $53.15^{\circ} \mathrm{N}$ and $56.4^{\circ} \mathrm{N}$ (Figure 10, RS2). This suggests a continuity between the eastern branch of the IC and the cross-ridge flow. This relationship is, however, not supported by the geostrophic transports at the time of the cruise because the cross-ridge transport was estimated at $0.5 \mathrm{~Sv}$ eastward (Figure 7). This discrepancy could be due to asynopticity between the southern section and the ridge section that were made 20 days apart. In the middle layer along $27.72 \sigma_{0}$, LSW properties in the branches of the IC (Figure $10, \mathrm{SS}_{\mathrm{EIC}}$ and $\mathrm{SS}_{\mathrm{WIC}}$ ) were fresher and colder than those of the cross-ridge flow (Figure 10, RS2) and close to those of the northern (subpolar) branch of the NAC at $52-53^{\circ} \mathrm{N}$ (Figure $10, \mathrm{RS}_{\mathrm{N}}$ ) suggesting that the IC is fed from the western basins. At the time of the cruise, the two IC branches at the southern section most likely followed the cyclonic circulation encompassing the Labrador and Irminger Seas, with some contribution from the Iceland Basin for the eastern branch in the upper layer. In the deep layer, there was only one significant ISOW core at the 


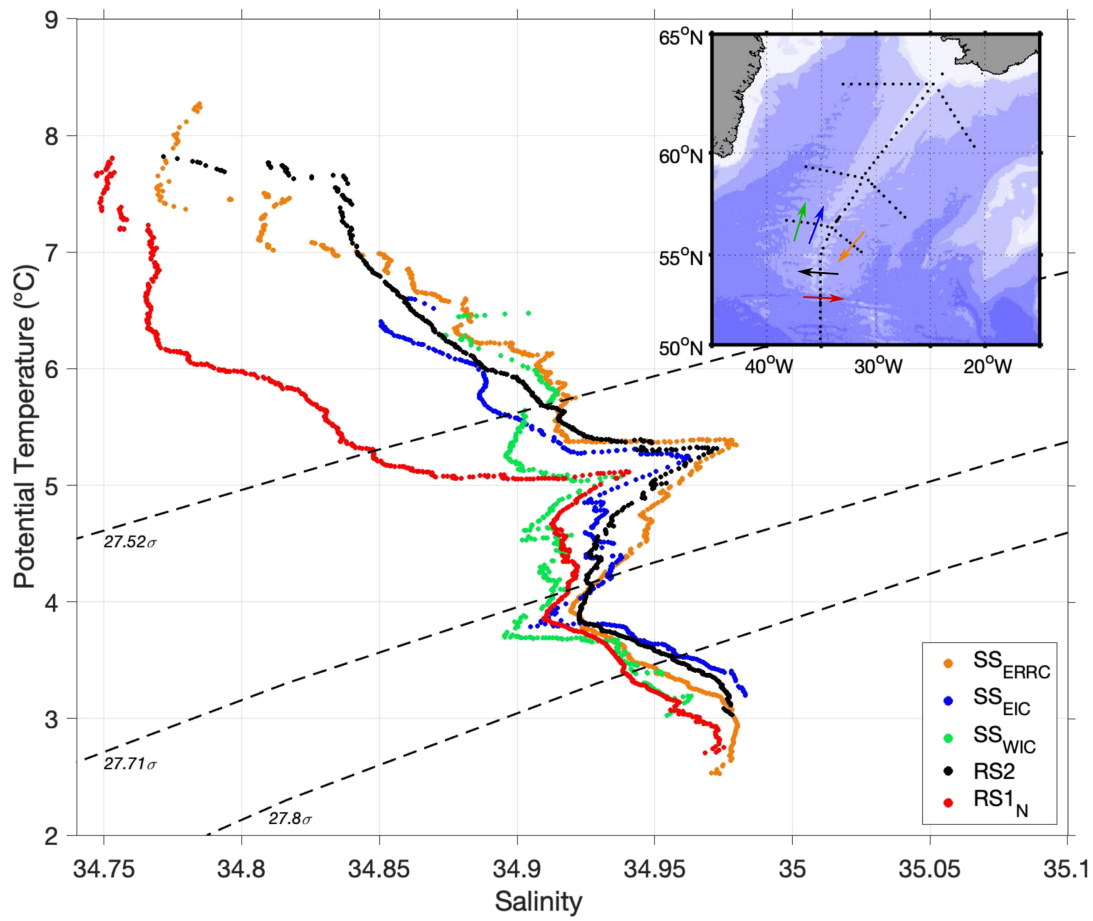

Figure 10. $\theta / \mathrm{S}$ diagram displaying the hydrographic profiles averaged along isopycnals of the eastern and western branches of the IC at the southern section ( $\mathrm{SS}_{\mathrm{EIC}}$, blue dots, and $\mathrm{SS}_{\mathrm{WIC}}$, green dots); of the ERRC at the southern section ( $\mathrm{SS}_{\mathrm{ERRC}}$, orange dots); across the ridge section in region 2 (RS2, black dots); and for the northern branch of the NAC $\left(\mathrm{RS}_{\mathrm{N}}\right.$, red dots). The dashed black lines indicate isopycnals $\sigma_{0}=27.52,27.71$, and $27.8 \mathrm{~kg} / \mathrm{m}^{3}$ that trace the limits of the upper and middle layers. (inserted map) bathymetric map of the North Atlantic with a 1,000-m spacing (darker blue is deeper) and indicating the color code of the $\theta /$ S diagram with the stations in black dots.

southern section below the western branch of the IC ( -200 to $-100 \mathrm{~km}$ in Figure 3). Fed from the CGFZ, this core was fresher and colder than ISOW in the Iceland Basin (Figure 10, $\mathrm{SS}_{\mathrm{WIC}}$ and $\mathrm{SS}_{\mathrm{ERRC}}$, respectively), in agreement with the downstream evolution of ISOW at and west of the CGFZ described by Racape et al. (2019).

We will now consider the connections and pathways between the southern and OVIDE sections. In addition to the flow from the southern section, the IC branches at the OVIDE section are influenced by inputs from both the Iceland Basin and Irminger Sea as shown by the volume budget (Figures 6 and 7) and by the intermediate position of their $\theta / \mathrm{S}$ profiles (Figure $9, \mathrm{OS}_{\mathrm{WIC}}$ and $\mathrm{OS}_{\mathrm{EIC}}$ ) compared with those of the IC from the southern section, the westward cross-ridge flow at the BFZ and the inflow from the Irminger Sea (Figures 3 and 9, $\mathrm{SS}_{\mathrm{EIC}}, \mathrm{SS}_{\mathrm{WIC}}, \mathrm{RS}_{\mathrm{BFZ}}$, and IG, respectively). Only the upper layer of the eastern IC branch shows a direct connection with the westward cross-ridge flow at the BFZ, as supported by the similarities of their $\theta / \mathrm{S}$ profile in the density range $27.6-27.71 \mathrm{~kg} / \mathrm{m}^{3}$ (Figure $9, \mathrm{OS}_{\mathrm{EIC}}$ and $\mathrm{RS}_{\mathrm{BFZ}}$, respectively). Overall, the IC transport increased from 9.8 to $23.5 \mathrm{~Sv}$ between the southern and OVIDE sections. In the upper layer, this increase in transport was mainly linked to the westward cross-ridge flow (3.1 Sv) that also caused a stronger northward warming and salinification of the IC eastern branch compared with the western branch. In the middle and deep layers, the inflows from the Iceland Basin and central Irminger Sea were of the same order of magnitude (about $4 \mathrm{~Sv}$ and less than $1 \mathrm{~Sv}$, respectively).

We will now consider the northward pathways of the IC between the OVIDE and northern sections. The origins of the IC branches at the northern section could be clearly identified from their $\theta / S$ profiles. In the upper layer, the eastern branch $(4.2 \mathrm{~Sv})$ is fed by the cross-ridge flow at $\mathrm{RS}_{\mathrm{N}}(7.1 \mathrm{~Sv})$ and thus by the ERRC at the northern section $(5.2 \mathrm{~Sv})$, while the western branch $(5.3 \mathrm{~Sv})$ was mainly fed by the cross-ridge flow at RS4 $\mathrm{S}$ $(4.3 \mathrm{~Sv})$ and thus by fresher inflow from the interior of the Iceland Basin (Figure 7), as supported by the similarity of the associated $\theta / \mathrm{S}$ profiles in Figure $8\left(\mathrm{NS}_{\mathrm{ERRC}}, \mathrm{RS}_{\mathrm{N}}\right.$ and $\mathrm{NS}_{\mathrm{EIC}}$ for the eastern IC branch, and $\mathrm{RS}_{\mathrm{S}}$ and $\mathrm{NS}_{\mathrm{WIC}}$ for the western IC branch). In the middle layer, the $4.5 \mathrm{~Sv}$ of the western IC branch originates 


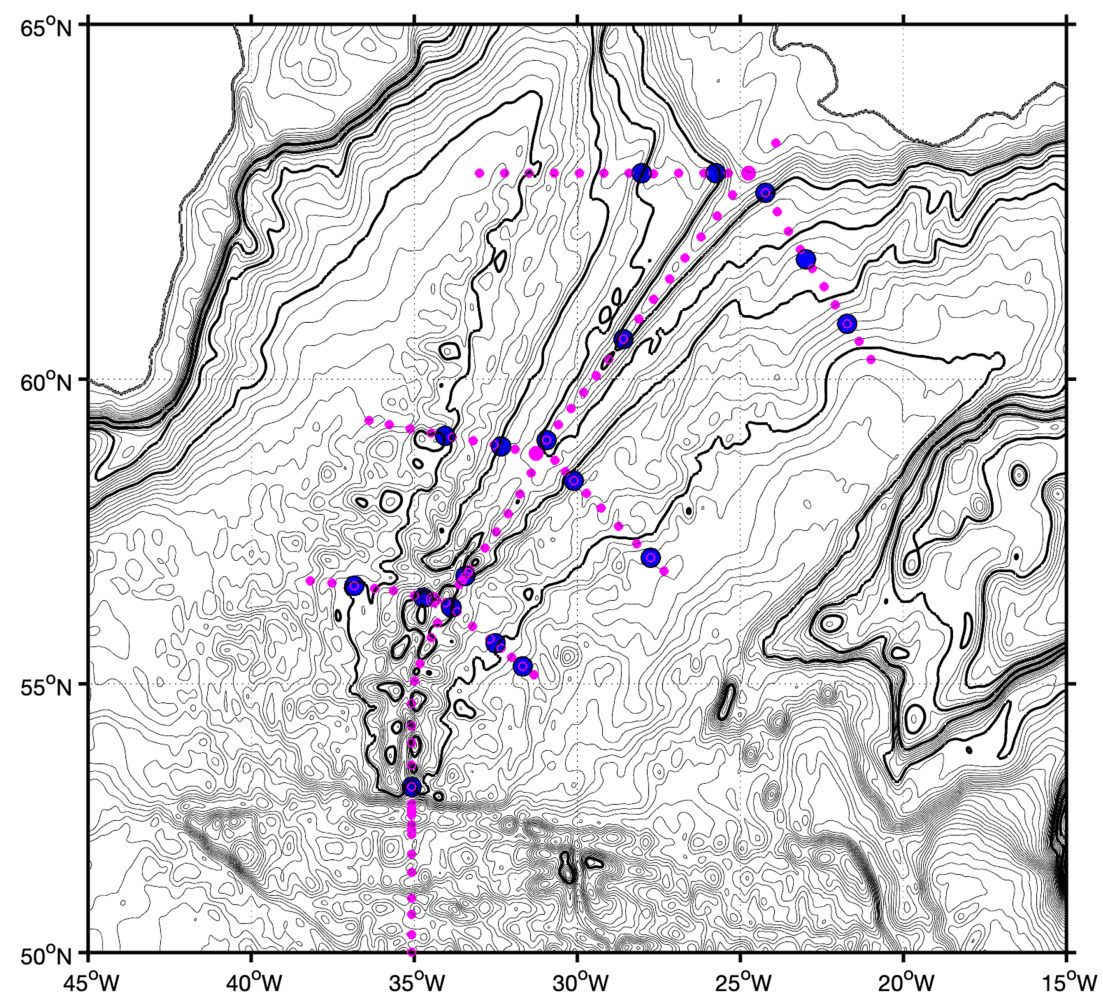

Figure 11. Smoothed contours of $\mathrm{f} / \mathrm{H}(\mathrm{m} / \mathrm{s})$ over the Reykjanes Ridge with an interval of $\mathrm{H}=100 \mathrm{~m}$, with bold black lines showing $\mathrm{H}=1,000 \mathrm{~m}, \mathrm{H}=1,400 \mathrm{~m}, \mathrm{H}=1,800 \mathrm{~m}$, and $\mathrm{H}=2,500 \mathrm{~m}$. Stations along the four sections are indicated by pink dots, with larger dots associated with the stations at $0 \mathrm{~km}$ above the ridge. Blue dots indicate the cores for the main southward flows in the Iceland Basin and northward flows in the Irminger Sea, as shown in Figure 3, as well as for the intensified flows across the ridge section.

from both the cross-ridge flow $\left(2.2 \mathrm{~Sv}\right.$ at $\mathrm{RS}_{\mathrm{S}}$ ) and the eastern branch of the IC at the OVIDE section ( $\left.2.3 \mathrm{~Sv}\right)$, as shown by the intermediate position of the $\theta / \mathrm{S}$ profile for the western IC branch at the northern section between those of the cross-ridge flow and eastern IC branch (Figure 8, $\mathrm{NS}_{\mathrm{WIC}}, \mathrm{RS}_{\mathrm{S}}$ and $\mathrm{OS}_{\mathrm{EIC}}$, respectively). The AVISO surface velocity data shown in Figure S2 provide support for such a strong outflow at these latitudes and the disconnection between the IC branches at the OVIDE and northern sections.

To conclude, although the IC was composed of two northward surface-intensified branches at the southern, OVIDE, and northern sections, we showed that these branches had different origins and along-stream evolutions. At the southern and OVIDE sections, the western branches were colder and fresher overall than the eastern branches because they incorporated larger volumes of fresh and cold waters from the interior of the Irminger Sea in the upper layers, while saltier inputs from the Iceland Basin strengthened the salinification of the eastern branches. This cross-ridge inflow accentuates the hydrological difference between the two IC branches at the OVIDE section. North of the OVIDE section, the two

Table 3

Transport (Sv) Across the Ridge Section Integrated Over Each Layer Defined in Table 2 and Over Each Segment Delimited by the Zonal Sections (Figure 4: RS1 South of $53.15^{\circ} \mathrm{N}$; RS2 Between $53.15-56.4^{\circ} \mathrm{N}$; RS3 Between $56.4-58.9^{\circ} \mathrm{N}$; $R S 4_{S}$ Between $58.9-60.3^{\circ} \mathrm{N} ; R S 4_{N}$ Between $60.3-63^{\circ} \mathrm{N}$ )

\begin{tabular}{lccccc}
\hline & $\mathrm{RS} 1$ & $\mathrm{RS} 2$ & $\mathrm{RS} 3$ & $\mathrm{RS} 4{ }_{\mathrm{S}}$ & $\mathrm{RS} 4_{\mathrm{N}}$ \\
\hline Upper layer & 20.1 & 0.5 & -3.1 & -4.3 & -7.1 \\
Middle layer & 13.3 & -0.1 & -3.6 & -2.2 & -0.2 \\
Deep layer & 6.8 & -1.1 & -0.9 & 0 & 0 \\
\hline
\end{tabular}
branches flowed toward the interior of the Irminger Sea and were disconnected from those at the northern section, which were mainly connected to westward cross-ridge flow.

\section{Discussion}

The connections of the IC and ERRC with flows across the Reykjanes Ridge and from the interior of the Iceland Basin and Irminger Sea caused large along-stream evolutions in their structures and hydrological properties (Figure 7). Here we discuss these evolutions in the light of previous 
results in the literature, discuss the role of eddies, and link the circulation with the bathymetry.

At the OVIDE section, the top-to-bottom ERRC transport was estimated at $-13.8 \pm 0.6 \mathrm{~Sv}$ (Table 2). Here Sarafanov et al. (2012) and Daniault et al. (2016) estimated mean ERRC transports of $-9.4 \pm 1.7 \mathrm{~Sv}$ (20022008) and $-12.1 \pm 1.1 \mathrm{~Sv}$ (2002-2012), respectively, which are slightly weaker than our synoptic estimate. These differences vary depending on the layer. In the upper and middle layers, Sarafanov et al. (2012) computed a mean transport of $-5.4 \pm 1.5 \mathrm{~Sv}$, and Daniault et al. (2016) computed a mean transport of $-8.9 \pm 0.6$ $\mathrm{Sv}$, while we obtained a higher ERRC transport of $-11.2 \pm 0.2 \mathrm{~Sv}$ (Table 2$)$. In the deep layer $\left(\sigma_{0} \geq 27.8\right.$ $\mathrm{kg} / \mathrm{m}^{3}$ ), Sarafanov et al. (2012) and Daniault et al. (2016) computed mean transports of $-4 \pm 0.4 \mathrm{~Sv}$ and $-3.2 \pm 0.4 \mathrm{~Sv}$, respectively. While our transport $(-2.6 \pm 0.3 \mathrm{~Sv})$ at these densities is weaker than the estimate of Sarafanov et al. (2012), it matches that of Daniault et al. (2016) within the error bars. As the values from Sarafanov et al. (2012) and Daniault et al. (2016) were for the early 2000s, the differences in the upper and middle layers are possibly related to the intensification of the subpolar gyre since the early 2010s (Foukal \& Lozier, 2017; Hátún \& Chafik, 2018; Zunino et al., 2017).

Using moorings located geographically closer to the Greenland-Scotland Ridge than our northern section, Kanzow and Zenk (2014) found a mean ISOW transport of $-3.8 \pm 0.6 \mathrm{~Sv}(2000-2002)$ at $60-64^{\circ} \mathrm{N}$. In our data set, the ISOW transport from the top of the ridge to $+325 \mathrm{~km}$ across the northern section was $-4.9 \pm 0.6 \mathrm{~Sv}$ (Figure 7). This result falls within the error bars of Kanzow and Zenk (2014) and thus agrees with their findings. To match the eastern limit of the mooring array at $21^{\circ} \mathrm{W}$ used by these previous authors, our ISOW transport estimates take into account the eastern core of ISOW in the northern section of the RREX data set, which is not included in the ERRC. In their work, Kanzow and Zenk (2014) also showed large differences of hydrological properties in the southward plume of ISOW, with larger fluctuations in the eastern core (see their Figure 9). They assumed that it was meander and recirculation that enhanced lateral water mass exchange between the ambient water and the eastern core. In the present study, we noted that the eastern vein of ISOW at $+250-300 \mathrm{~km}$ at the northern section, which is fresher and colder overall than the western veins, has a variable $\theta / \mathrm{S}$ profile (not shown) and, interestingly, is adjacent to a strong top-to-bottom eddy of the NAC (Figure 3 and at $20-22^{\circ} \mathrm{W} / 59-60.5^{\circ} \mathrm{N}$ in Figure 5).

We will now consider ISOW transports along the three sections on the eastern side of the Reykjanes Ridge. For the northern section, the ISOW transport at the OVIDE section includes transport of an eastern ISOW core (at $+200 \mathrm{~km}$ in Figure 3). The ISOW transport at the OVIDE section $(-5.3 \pm 0.3 \mathrm{~Sv})$ is consistent with that at the northern section $(-4.9 \pm 0.6$ in Figure $7 \mathrm{c})$. Volume conservation between the OVIDE section and southern section suggests that the ISOW transport at OVIDE feeds the ISOW transport through the BFZ $(-0.9 \pm 0.8 \mathrm{~Sv})$ and at the southern section $(-4.2 \pm 0.5 \mathrm{~Sv})$.

Although the ERRC largely feeds the IC through the Reykjanes Ridge, Jakobsen et al. (2003) showed that the ERRC was weaker at subsurface depths than was the IC (see Figures 3 and 5, therein). Moreover, Treguier et al. (2005) showed that various high-resolution numerical models also showed weaker ERRC than IC at the surface and at $700 \mathrm{~m}$ (see Figures 2 and 3, therein). Here we showed that, in the top 1,000 m, the strengths of these two currents are of the same order of magnitude at both the OVIDE and southern sections $(0.21 \mathrm{~m} / \mathrm{s}$ and $0.1 \mathrm{~m} / \mathrm{s}$, respectively, Figure 3). This suggests that the maps of surface and subsurface velocities derived from drifters and satellite altimetry do not reproduce the strength of the narrow southward ERRC correctly, possibly because their altimetric velocities have been averaged over a large horizontal distance in previous studies, and that the parameterization for numerical models does not suit the observations in this region (Rattan et al., 2010; Treguier et al., 2005).

At about $59^{\circ} \mathrm{N}$, Våge et al. (2011) showed that the western and eastern branches of the IC have different properties, the western branch containing more subpolar water than the eastern branch. This difference was explained by the circulation of the NAC in the Iceland Basin: the warmer outer rim branch of the NAC feeding the eastern IC branch and the colder inner branch of the NAC feeding the western IC branch (Bower et al., 2002; Lavender et al., 2000; Ollitrault \& Colin de Verdière, 2014; Våge et al., 2011). Here we showed that the hydrological differences between the two IC branches (Figures 8-10) are not solely due to the circulation of the NAC in the Iceland Basin, but also to fresh and cold inflows from the center of the Irminger Sea or Labrador Sea that join the western branch of the IC without entering the Iceland Basin (Figure 7). South of the southern section, this inflow follows the dynamic topography contour $-0.55 \mathrm{~m}$ on Figure 5. Using drifter data, Jakobsen et al. (2003) and Faure and Speer (2005) also showed surface 
pathways that directly link the western basins to the IC at these latitudes (Faure \& Speer, 2005, their Figure 9 ; Jakobsen et al., 2003, their Figure 5). The baroclinic transport of this inflow was estimated at 8 Sv in the top $1,400 \mathrm{~m}$ by Pollard et al. (2004) from synoptic surveys. In the western branch of the IC at the southern section, we estimated a baroclinic transport of $7 \pm 1 \mathrm{~Sv}$, which is in good agreement with their results. The lack of clear connection between the Iceland Basin and the IC south of the southern section implies that part of the ERRC veers eastward and recirculates in the Iceland Basin, which was also shown by floats at $700 \mathrm{~m}$ (Lavender et al., 2000, their Figure 2a) and by numerical models (Treguier et al., 2005, their Figure 3a). Similarly, between the southern section and the OVIDE section, Reverdin et al. (2003) and Lazarevich et al. (2004) showed drifters and RAFOS floats joining the IC from the center of the Irminger Sea (Lazarevich et al., 2004, their Figure 2; Reverdin et al., 2003, their Figure 12). At these latitudes however, we showed that the westward cross-ridge flow, which is strong at the BFZ (Petit, Mercier, et al., 2018), plays a major role in the along-stream evolution of IC properties and causes an overall warming and salinification of the two IC branches (Figure 9).

North of the OVIDE section, we showed that the IC is largely exported northwestward toward the interior of the Irminger Sea (Figures 7 and S2). The IC branches at the northern section are thus mainly fed by surface and intermediate inflows from the Iceland Basin. This is consistent with results from drifters used by Reverdin et al. (2003) and modeled surface currents of Treguier et al. (2005), who showed a northwestward outflow at these latitudes (Reverdin et al., 2003, their Figure 12; Treguier et al., 2005, their Figures 2 and 3). In their paper, Treguier et al. (2005) explained that circulation around the Reykjanes Ridge follows the $\mathrm{f} / \mathrm{H}$ contours. They nevertheless noted that the models were more influenced by the bathymetry than the observations, due to their resolutions $\left(1 / 12^{\circ}\right)$ that could not reproduce complex instabilities. In Figure 11 , the $\mathrm{f} / \mathrm{H}$ contours for $\mathrm{H}>1,800 \mathrm{~m}$ deviate northwestward from the top of the Reykjanes Ridge (also seen in Figure 1 of Treguier et al., 2005). The pathways of the IC branches north of the OVIDE section thus seem influenced by two factors. First, they are steered northwestward by the $\mathrm{f} / \mathrm{H}$ contours, but because the pathways tend to flow toward deeper regions (Figure S2) it is possible that the westward cross-ridge flow may further deviate the IC originating from the OVIDE section westward. We finally note that, as in Treguier et al. (2005) analysis, the cross-ridge flows that feed the IC at the southern, OVIDE, and northern sections follow f/H contours (Figure 11).

Finally, during the RREX2015 cruise, a southward meander from the Irminger Gyre northward rim was localized west of the IC at the OVIDE section ( -300 to $-200 \mathrm{~km}$ in Figure 3). At OVIDE latitudes, Sarafanov et al. (2012) and Daniault et al. (2016) also observed a southward flow west of the IC in each year of their repeated transatlantic sections. By including this southward meander, they estimated an averaged IC transport of $13.0 \pm 1.9 \mathrm{~Sv}$ (2002-2008) and 9.5 \pm 3.4 Sv (2002-2012), respectively. For the same limits, we computed an IC transport of $15.6 \pm 0.8 \mathrm{~Sv}$ (Figure 4), which remains within the range of the high interannual variability reported by Våge et al. (2011) over 16 years (1991-2007). To explain this high variability, Daniault et al. (2016) highlighted the variable intensity of the southward meander over the 6 years of OVIDE observations, which could reach 10.5 Sv southward (Daniault et al., 2016, their Figure 2 at about $34-35^{\circ} \mathrm{W}$ ). One may therefore think that this southward meander could be involved in the mixing between the Irminger Gyre and the IC. Indeed, Fan et al. (2013) and Sy et al. (1997) have already noted that the strong eddy activity at these latitudes favors mixing on isopycnals. As this southward meander seems to play a significant role in the variability of the IC, it would also be of great interest to clarify its connection to the IC, as well as the occurrence and cause of its formation west of the IC, but this is beyond the scope of our present analysis.

\section{Conclusion}

The RREX data set allowed us to make an in-depth investigation of the circulation around and over the Reykjanes Ridge as observed during summer 2015. Based on geostrophic and Ekman transports along four synoptic sections across and along the top of the Reykjanes Ridge, we described the evolution and formation of the ERRC and IC on both sides of the ridge at the time of the cruise, as well as the effect of the bathymetry on their connections.

Defined as southward flows within a width of about $200 \mathrm{~km}$ east of the top of the Reykjanes Ridge (Daniault et al., 2016), we estimated the ERRC at $-10.6 \pm 0.9 \mathrm{~Sv}$ at the northern section, $-13.8 \pm 0.6 \mathrm{~Sv}$ at the OVIDE section, and $-13.0 \pm 1.2 \mathrm{~Sv}$ at the southern section. Likewise, the IC was defined by two surface-intensified 
northward flows within about $200 \mathrm{~km}$ west of the top of the Reykjanes Ridge (Våge et al., 2011) and was estimated at $15.7 \pm 0.9 \mathrm{~Sv}$ at the northern section, $23.5 \pm 0.6 \mathrm{~Sv}$ at OVIDE section, and $9.8 \pm 1 \mathrm{~Sv}$ at southern section. At OVIDE latitudes, the IC and ERRC transports are therefore larger than at other latitudes due to their interactions with the interior of the Iceland Basin and Irminger Sea.

The horizontal and vertical structures of the ERRC along the Reykjanes Ridge showed for the first time that this current does not have identical characteristics north and south of the OVIDE latitudes. The ERRC is continuously evolving in shape and transport due both to inflows from the Iceland Basin reinforcing it and outflows through the Reykjanes Ridge weakening it as soon as they are no longer blocked by the bathymetry. The top-to-bottom barotropic ERRC observed at OVIDE latitudes by Daniault et al. (2016) is thus formed by a local convergence of southward flows, which combine inflows from the NAC at the surface and ERRC waters blocked by the Reykjanes Ridge at depth. Downstream, part of ISOW flows through the BFZ and possibly explains the lack of bottom-intensified core at about 2,000-m depth at the southern section and thus the surface-intensified structure of the ERRC branch at $0-50 \mathrm{~km}$. These lateral exchanges also cause the along-stream freshening and cooling in its upper and middle layers.

On the western side of the Reykjanes Ridge, the IC is not solely fed by inflows from the Iceland Basin, but also by subpolar waters from the western basins that join the IC before entering the Iceland Basin. The western branch of the IC, which is more influenced by these subpolar inflows, is fresher and colder than the eastern branch, which is more influenced by inflows from the Iceland Basin. Nevertheless, the inflows from the Iceland Basin over the Reykjanes Ridge cause the overall warming and salinification of the IC branches from the southern section to the northern section. The largest impact of these inflows on the properties and circulation of the IC is observed between the OVIDE section and northern section. There, the IC is largely deflected toward the center of the Irminger Sea, following the $\mathrm{f} / \mathrm{H}$ contours and the horizontal circulation of the East Greenland Current afterwards, such that the two IC branches at the northern section are mainly fed by the cross-ridge flows in the upper and middle layers. Neither the ERRC nor the IC branches should therefore be seen as continuous flows along the Reykjanes Ridge, but as conduits combining, in changing proportions, subpolar waters from the western basins and warmer and saltier waters following the horizontal circulation in the Iceland Basin.

\section{References}

Bower, A., \& Furey, H. (2017). Iceland-Scotland Overflow Water transport variability through the Charlie-Gibbs Fracture Zone and the impact of the North Atlantic Current. Journal of Geophysical Research: Oceans, 122, 6989-7012. https://doi.org/10.1002/2017JC012698 Bower, A., Le Cann, B., Rossby, T., Zenk, W., Gould, J., Speer, K., et al. (2002). Directly measured mid-depth circulation in the northeastern North Atlantic Ocean. Nature, 419(6907), 603-607. https://doi.org/10.1038/nature01078

Bower, A., \& von Appen, W.-J. (2008). Interannual variability in the pathways of the North Atlantic current over the Mid-Atlantic Ridge and the impact of topography. Journal of Physical Oceanography, 38(1), 104-120. https://doi.org/10.1175/2007JPO3686.1

Branellec, P., \& Thierry, V. (2016). RREX 2015. CTD-02 Data report. ODE/LOPS/16-26. https://doi.org/http://doi.org/10.13155/47156

Chafik, L., Rossby, T., \& Schrum, C. (2014). On the spatial structure and temporal variability of poleward transport between Scotland and Greenland. Journal of Geophysical Research: Oceans, 119, 824-841. https://doi.org/10.1002/2013JC009287

Childers, K., Flagg, C. N., Rossby, T., \& Schrum, C. (2015). Directly measured currents and estimated transport pathways of Atlantic Water between $59.58 \mathrm{~N}$ and the Iceland Faroes Scotland Ridge. Tellus, 67, 28067. https://doi.org/10.3402/tellusa.v67.28067

Daniault, N., Mercier, H., Lherminier, P., Sarafanov, A., Falina, A., Zunino, P., et al. (2016). The northern North Atlantic Ocean mean circulation in the early 21st century. Progress in Oceanography, 146, 142-158. https://doi.org/10.1016/j.pocean.2016.06.007

de Boisséson, E. (2010). Eaux modales subpolaires du Bassin d'Islande: Origine, formation et variabilité. Brest, France: University of Bretagne Occidentale.

Dee, D. P., Uppala, S. M., Simmons, A. J., Berrisford, P., Poli, P., Kobayashi, S., et al. (2011). The ERA-Interim reanalysis: Configuration and performance of the data assimilation system. Quarterly Journal of the Royal Meteorological Society, 137(656), 553-597. https://doi.org/ $10.1002 /$ qj. 828

Fan, X., Send, U., Testor, P., Karstensen, J., \& Lherminier, P. (2013). Observations of Irminger Sea Anticyclonic Eddies. Journal of Physical Oceanography, 43(4), 805-823. https://doi.org/10.1175/JPO-D-11-0155.1

Faure, V., \& Speer, K. (2005). Labrador Sea Water circulation in the Northern North Atlantic Ocean. Deep-Sea Research Part II: Topical Studies in Oceanography, 52(3-4), 565-581. https://doi.org/10.1016/j.dsr2.2004.12.004

Foukal, N. P., \& Lozier, M. S. (2017). Assessing variability in the size and strength of the North Atlantic subpolar gyre. Journal of Geophysical Research: Oceans, 122, 6295-6308. https://doi.org/10.1002/2017JC012798

Gourcuff, C., Lherminier, P., Mercier, H., \& Le Traon, P. Y. (2011). Altimetry combined with hydrography for ocean transport estimation. Journal of Atmospheric and Oceanic Technology, 28(10), 1324-1337. https://doi.org/10.1175/2011JTECHO818.1

Hátún, H., \& Chafik, L. (2018). On the recent ambiguity of the North Atlantic subpolar gyre index. Journal of Geophysical Research: Oceans, 123, 5072-5076. https://doi.org/10.1029/2018JC014101

Jakobsen, P. K., Ribergaard, M. H., Quadfasel, D., Schmith, T., \& Hughes, C. W. (2003). Near-surface circulation in the northern North Atlantic as inferred from Lagrangian drifters: Variability from the mesoscale to interannual. Journal of Geophysical Research, 108(C8), 3251. https://doi.org/10.1029/2002JC001554 
Kalnay, E., Kanamitsu, M., Kistler, R., Collins, W., Deaven, D., Gandin, L., et al. (1996). The NCEP/NCAR 40-year reanalysis project. Bulletin of the American Meteorological Society, 77(3), 437-471. https://doi.org/10.1175/1520-0477(1996)077<0437:TNYRP>2.0.CO;2

Kanzow, T., \& Zenk, W. (2014). Structure and transport of the Iceland Scotland Overflow plume along the Reykjanes Ridge in the Iceland Basin. Deep-Sea Research Part I: Oceanographic Research Papers, 86, 82-93. https://doi.org/10.1016/j.dsr.2013.11.003

Knutsen, Ø., Svendsen, H., Østerhus, S., Rossby, T., \& Hansen, B. (2005). Direct measurements of the mean flow and eddy kinetic energy structure of the upper ocean circulation in the NE Atlantic. Geophysical Research Letters, 32, L14604. https://doi.org/10.1029/ 2005GL023615

Lavender, K. L., Davis, R. E., \& Owens, W. B. (2000). Mid-depth recirculation observed in the interior Labrador and Irminger seas by direct velocity measurements. Nature, 407(6800), 66-69. https://doi.org/10.1038/35024048

Lazarevich, P., Rossby, T., \& McNeil, C. (2004). Oxygen variability in the near-surface waters of the northern North Atlantic: Observations and a model. Journal of Marine Research, 62, 663-683. https://doi.org/10.1357/0022240042387547

Lherminier, P., Mercier, H., Gourcuff, C., Alvarez, M., Bacon, S., \& Kermabon, C. (2007). Transports across the 2002 Greenland-Portugal Ovide section and comparison with 1997. Journal of Geophysical Research, 112, C07003. https://doi.org/10.1029/2006JC003716

Mercier, H., Lherminier, P., Sarafanov, A., Gaillard, F., Daniault, N., Desbruyères, D., et al. (2015). Variability of the meridional overturning circulation at the Greenland-Portugal OVIDE section from 1993 to 2010. Progress in Oceanography, 132, 250-261. https://doi. org/10.1016/j.pocean.2013.11.001

Ollitrault, M., \& Colin de Verdière, A. (2014). The ocean general circulation near 1000-m depth. Journal of Physical Oceanography, 44(1), 384-409. https://doi.org/10.1175/JPO-D-13-030.1

Otto, L., \& Van Aken, H. M. (1996). Surface circulation in the northeast Atlantic as observed with drifters. Deep-Sea Research Part I Oceanographic Research Papers, 43(4), 467-499. https://doi.org/10.1016/0967-0637(96)00017-9

Petit, T., Mercier, H., \& Thierry, V. (2018). First direct estimates of volume and water mass transports across the Reykjanes Ridge. Journal of Geophysical Research: Oceans, 123, 6703-6719. https://doi.org/10.1029/2018JC013999

Petit, T., Thierry, V., \& Mercier, H. (2018). RREX 2015. S-ADCP data processing report. LOPS/18-01 (March 2018). https://doi.org/http:// doi.org/10.13155/53471

Pollard, R. T., Read, J. F., Holliday, N. P., \& Leach, H. (2004). Water masses and circulation pathways through the Iceland basin during Vivaldi 1996. Journal of Geophysical Research, 109, C04004. https://doi.org/10.1029/2003JC002067

Racape, V., Thierry, V., Mercier, H., \& Cabanes, C. (2019). ISOW spreading and mixing as revealed by Deep-Argo floats launched in the Charlie Gibbs Fracture Zone. Journal of Geophysical Research: Oceans, 124, 6787-6808. https://doi.org/10.1029/2019JC015040

Rattan, S., Myers, P. G., Treguier, A.-M., Theetten, S., Biastoch, A., \& Böning, C. (2010). Towards an understanding of Labrador Sea salinity drift in eddy-permitting simulations. Ocean Modelling, 35(1-2), 77-88. https://doi.org/10.1016/J.OCEMOD.2010.06.007

Reverdin, G., Niiler, P. P., \& Valdimarsson, H. (2003). North Atlantic Ocean surface currents. Journal of Geophysical Research, 108(C1), 3002. https://doi.org/10.1029/2001JC001020

Roessler, A., Rhein, M., Kieke, D., \& Mertens, C. (2015). Long-term observations of North Atlantic Current transport at the gateway western and eastern Atlantic. Journal of Geophysical Research: Oceans, 120, 4003-4027. https://doi.org/10.1002/2014JC010662

Sarafanov, A., Falina, A., Mercier, H., Sokov, A., Lherminier, P., Gourcuff, C., et al. (2012). Mean full-depth summer circulation and transports at the northern periphery of the Atlantic Ocean in the 2000s. Journal of Geophysical Research, 117, C01014. https://doi.org/ 10.1029/2011JC007572

Schott, F., Stramma, L., \& Fischer, J. (1999). Interaction of the North Atlantic Current with the deep Charlie Gibbs Fracture Zone throughflow. Geophysical Research Letters, 26(3), 369-372. https://doi.org/10.1029/1998GL900223

Sy, A., Rheint, M., Lazier, J. R. N., Koltermann, K. P., Meincke, J., Putzka, A., \& Bersch, M. (1997). Surprisingly rapid spreading of newly formed intermediate waters across the North Atlantic Ocean. Nature, 386(6626), 675-679. https://doi.org/10.1038/386675a0

Thierry, V., Mercier, H., Petit, T., Branellec, P., \& Balem, K. (2018). Reykjanes Ridge experiment (RREX) dataset. SEANOE. http://doi.org/ $10.17882 / 55445$

Treguier, A. M., Theetten, S., Chassignet, E. P., Penduff, T., Smith, R., Talley, L., et al. (2005). The North Atlantic subpolar gyre in four highresolution models. Journal of Physical Oceanography, 35(5), 757-774. https://doi.org/10.1175/JPO2720.1

Våge, K., Pickart, R. S., Sarafanov, A., Knutsen, Ø., Mercier, H., Lherminier, P., et al. (2011). The Irminger Gyre: Circulation, convection, and interannual variability. Deep-Sea Research Part I: Oceanographic Research Papers, 58(5), 590-614. https://doi.org/10.1016/j dsr.2011.03.001

Valdimarsson, H., \& Malmberg, S. (1999). Near-surface circulation in Icelandic waters derived from satellite tracked drifters. Rit Fiskideildar, (Vol. 16, pp. 23-39), Reykjavík, Iceland: Rit Fiskideildar. Retrieved from papers://f554698c-bc30-43aa-8c0c-c8de8adb48e4/ Paper/p1548

Yashayaev, I., Bersch, M., \& van Aken, H. M. (2007). Spreading of the Labrador Sea Water to the Irminger and Iceland basins. Geophysical Research Letters, 34, L10602. https://doi.org/10.1029/2006GL028999

Zunino, P., Lherminier, P., Mercier, H., Daniault, N., García-Ibáñez, M. I., \& Pérez, F. F. (2017). The GEOVIDE cruise in May-June 2014 reveals an intense Meridional Overturning Circulation over a cold and fresh subpolar North Atlantic. Biogeosciences, 14(23), 5323-5342. https://doi.org/10.5194/bg-14-5323-2017 